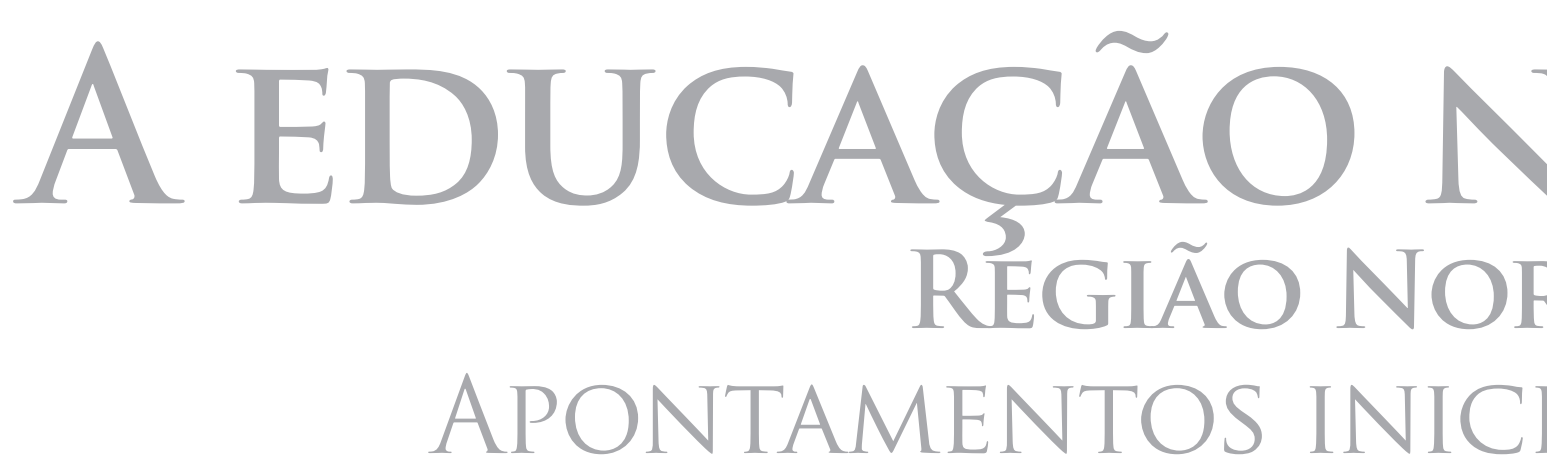




\section{A EDUCAÇÃO NA REGIÃO NORTE: APONTAMENTOS INICIAIS}

\section{MARIA APARECIDA DA SILVA B E NTO}

Centro de Estudos das Relações de Trabalho e Desigualdades, Brasil

$$
\begin{array}{r}
\text { W I L M A D E N A Z A R É B A I A C O E L H O } \\
\text { Universidade Federal do Pará, Brasil }
\end{array}
$$

$$
\text { MAURO CEZAR COE LHO }
$$

UNIVERSIDADE FEDERAL DO PARÁ, BRASIL

DANIELA MARTINS PEREIRA FERNANDES

Centro de Estudos das Relações de Trabalho e Desigualdades, Brasil 


\title{
A EDUCAÇÃO NA REGIÃO NORTE: APONTAMENTOS INICIAIS
}

\section{Resumo}

Este texto aborda aspectos da educação na região Norte, em particular, no Estado do Pará; oferece um enfoque sobre a diversidade cultural, especialmente a educação no campo, quilombola e indígena. Centrase na análise de documentos e projetos das organizações parceiras do Programa "Norte de Saberes". Conclui-se que a educação na Região Norte requer análises circunstanciadas sobre as suas diversas dimensões. Há que se salientar que os processos articulados pelos coletivos da sociedade civil são alvissareiros, ao pautar a construção coletiva de uma proposta democrática de educação de qualidade, que considere a diversidade territorial e humana, e a superação das desigualdades.

Palavras-chave: Formação de professores, ensino médio, relações étnicoraciais

\section{EDUCATION IN NORTH REGION BRAZIL: FIRST NOTES}

\begin{abstract}
This paper discusses aspects of the education in the North region, in particular, in the State of Pará; offers a focus on cultural diversity, especially concern on the education of indigenous peoples, maroon and peasants' communities. It analyses documents and projects of partner organizations of the "North of Knowledge" Program. We conclude that education in the North requires detailed analysis on its various dimensions. It should be noted that the processes articulated by civil society are collective good cheer, to guide the construction of a proposed collective democratic quality education that considers the territorial diversity and human, and overcoming inequalities.
\end{abstract}

Keywords: Teacher education, high school, racial-ethnic relations.

\section{L'ÉDUCATION DANS LE NORD DU BRÉSIL: LES PREMIÈRES NOTES}

\section{Résumé}

Ce document examine les aspects de l'éducation dans le Nord, en particulier, l'État du Pará, propose l'accent sur la diversité culturelle, en particulier dans le domaine de l'éducation, marron et autochtones. Met l'accent sur l'analyse des documents et des projets des organisations partenaires du «Nord de la connaissance». Nous concluons que l'éducation dans le Nord exige une analyse approfondie sur ses différentes dimensions. Il 
convient de noter que les processus énoncés par la société civile sont la bonne humeur collective, afin de guider la construction d'une éducation de qualité démocratique collective proposée qui tient compte de la diversité territoriale et humaine, et lutte contre les inégalités.

Mots-clés: formation des enseignants, high school, relations racialeethnique.

MARIA APARECIDA DA SILVA BENTO. Endereço para correspondência: Rua Diana 715 apto 102 A - Perdizes, São Paulo -SP, CEP 05019000. E-mail: cibento@uol.com.br 


\section{INTRODUÇÃO}

$\mathrm{Na}$ construção deste texto, duas dimensões da realidade amazônica foram recorrentes nos estudos e artigos pesquisados, nos documentos, bem como nos projetos das organizações parceiras do Programa "Norte de Saberes": de um lado o destaque dado à rica diversidade humana, dispersa num vasto território repleto de recursos naturais, e de outro a constatação da imensa desigualdade econômica e social que contrasta com as demais regiões do Brasil, bem como com as riquezas naturais da própria região. A riqueza que a distingue é uma condição que sempre aparece junto com elementos como cobiça e ganância, que se revelam presentes na história de exclusão e expropriação da região.

Boa parte do que se pensa sobre a Amazônia é estendido para a região Norte, composta pelos Estados do Acre, Amapá, Amazonas, Pará, Tocantins, Rondônia e Roraima; apenas um deles encontra-se fora da área da grande floresta equatorial. A região Norte possui uma vasta área geográfica $-3.853 .322,2 \mathrm{~km} 2$, com aproximadamente 16 milhões de habitantes, dos quais cerca de $38 \%$ são crianças e adolescentes até 17 anos, ${ }^{1}$ constituindo, portanto, a população mais jovem de todo o País.

A educação nesta região está necessariamente ligada à diversidade das condições de vida local, de saberes, de valores, de práticas sociais e educativas, bem como de uma variedade de sujeitos, camponeses e citadinos (populações urbanas e periféricas das cidades da Amazônia). Corroborando com a diversidade de condições de vida na região, seus dois maiores estados, Amazonas e Pará, possuem distribuição populacional praticamente oposta. Enquanto o Amazonas concentra cerca de $70 \%$ de sua população na capital, no Estado do Pará o mesmo percentual é distribuído no interior do Estado ficando apenas cerca de 30\% na região metropolitana de Belém.

A diversidade de sujeitos da região coloca, dentre tantos desafios, o de construir sua própria história, contrapondo-se à maneira com que esta vem sendo engendrada por pessoas oriundas de outras regiões do Brasil ou de outros países, que muitas vezes veem e utilizam a região a partir da perspectiva colonialista, de exploração das riquezas naturais e do conhecimento da população local.

Diante deste contexto, cabe salientar que reunir dados sobre a educação na região Norte do Brasil é uma tarefa complexa, considerando este cenário de condições difíceis, muitas vezes extremas. As contradições aparecem o tempo todo. Se esta região possui a maior e mais profusa rede de rios e igarapés do País, em algumas escolas não há água potável para as crianças beberem.

A riqueza de recursos de mineração, agropecuários e fluviais é tanta que atrai aventureiros de diversas partes do mundo; no entanto, o esgoto a céu aberto revela-se realidade bastante recorrente no Norte: 32,2\%, segundo censo de 2010; os domicílios com saneamento adequado são apenas $22,4 \%$, porcentagem baixíssima, especial- 
mente ao se comparar com o que se verifica no Sudeste: $82,3 \%$. Por outro lado, em razão de conflitos agrários, nos últimos dez anos 1.855 pessoas sofreram ameaças de morte no Brasil; a maioria das ocorrências concentrase nos Estados da Amazônia Legal, sobretudo no Pará, onde ocorreram 621 mortes no período (IPEA 2012: 247-254). Outro dado é que, se por um lado somente para o Norte estão estimados investimentos da ordem de 212 bilhões de reais até 2020 , abrangendo a construção de 11 hidrelétricas, a construção e/ou extensão de ferrovias integradoras e a expansão de atividades mineradoras, de outro lado a região Norte é aquela que tem o maior percentual de escolas rurais fechadas: entre 2002 e 2010, Rondônia fechou 63\% e Tocantins 40\% de suas escolas rurais. Também vale lembrar que se encontra nas regiões Norte e Nordeste mais da metade da população rural em extrema pobreza no Brasil; ou seja, riqueza e desigualdades convivem lado a lado (IPEA 2012).

No entanto, cumpre salientar que este cenário encerra em si uma forte tensão que vem mobilizando a sociedade civil, de maneira muitas vezes dramática, provocando o Poder Público para sair de sua inércia e fazendo emergir uma singular capacidade de questionar elementos fundantes da educação brasileira, fortemente ancorada numa perspectiva ocidental, urbanocêntrica e eurocêntrica, trazendo para o primeiro plano a riqueza da realidade local e a alvissareira possibilidade de construção coletiva dos processos educacionais.

\section{EDUCAÇÃO NA REGIÃO NORTE}

A região Norte é muitas vezes percebida como um grande repositório de riquezas naturais, as quais aguardam a sua transformação em commodities valorizadas. Tal como a Amazônia, a região é vista como promessa. Sua importância, para o imaginário a ela relacionado, não raro, reside mais no que ela pode vir a ser e menos no que é propriamente.

Isto se deve, em larga medida, ao imaginário construído em torno da região, desde o século XVI. As dimensões superlativas da natureza amazônica assombraram e maravilharam gerações seguidas de exploradores que enalteceram a paisagem natural (Gondin 2009). A humanidade da região, no entanto, não conheceu o mesmo entusiasmo. Seus grupos humanos padeceram, desde o início da conquista europeia, das formulações elaboradas em relação aos povos indígenas - objeto de uma intensa controvérsia, por meio da qual se discutia, inclusive, a sua humanidade (Gerbi 1993). Para muitos dos comprometidos com a conquista europeia, os povos indígenas eram incapazes de gerir o próprio destino - a aparente dependência da natureza lhes parecia uma evidência eloqüente (Colaço 1999).

A região Norte é herdeira dessa trajetória histórica. Sua humanidade é percebida por meio dos filtros construídos desde as crônicas dos primeiros viajantes - o que engendra algumas confusões (Cunha 1975). A maior delas, talvez, atribui aos povos da região a responsabilidade pelo atraso em que vivem. Esquecem-se, no entanto, os detratores da humanidade amazônica, 
que vários dos seus problemas são resultado de circunstâncias históricas. Nenhum deles se origina de atavismos ou de questões a eles vinculadas. E que a caracterização de atraso por indicadores como o IDH (Índice de Desenvolvimento Humano) está pautada em uma lógica urbanocêntrica que ignora que, apesar da falta de condições adequadas de educação formal e saúde, o amazônida de comunidades tradicionais não exibe as fragilidades nutricionais observadas em outras partes pouco favorecidas do mundo e utiliza os recursos florestais de modo sustentável, inclusive no trato de enfermidades leves, guardando muitas e ricas lições para a humanidade (Brito 2012).

Na verdade, o que é considerado "atraso" explicita o resultado das políticas de desenvolvimento concebidas ou implementadas na Amazônia, nas quatro últimas décadas. Podem-se destacar aqui os projetos agropecuários, hidrelétricos e de mineração, que se localizam, em grande parte, no Pará e determinaram uma infraestrutura tecnológica bem como padrões de ocupação e colonização centrados somente no acesso, uso e controle dos recursos naturais. Este padrão vem gerando exclusão social e expulsão da população rural para as periferias das pequenas e médias cidades, bem como ocupação de bens públicos, gerando ainda conflitos de terra e violência no campo. Os dados educacionais da região refletem essa desigualdade.

$\mathrm{Na}$ região Norte, os índices de desempenho das escolas são os piores do Brasil, segundo o IDEB - Índice de
Desenvolvimento da Educação Básica. Quanto a isso, cabe a discussão sobre como articular uma forma de avaliação verdadeiramente "universal" que, ao mesmo tempo em que reúna elementos que sejam comuns às escolas de todo o País, possibilite a inclusão efetiva dos saberes locais, das diferentes regiões. Provavelmente, na construção desta outra concepção de avaliação, a presença dos sujeitos locais tornar-se-á imprescindível. No entanto, considerando-se o processo de avaliação atual, não se pode negar que o baixo desempenho das escolas na região Norte, particularmente no que diz respeito ao ensino médio, merece atenção. Outras regiões do Brasil padecem da mesma dificuldade, no sentido da necessidade de uma avaliação mais articulada com as localidades e, ainda assim, vêm conseguindo um desempenho melhor no índice. O que significa esta diferença? Que impacto pode ter no futuro escolar e profissional dos jovens oriundos de escolas desta região? Quando comparamos o desempenho no IDEB da região Norte e do Pará com o do Brasil no período entre 2005 e 2011 (Figura 1), observamos uma melhora gradativa nos índices, mas a situação desta região e do Pará com relação ao Brasil é negativa e ainda bastante significativa (Brito 2012).

Sendo a região mais jovem do Brasil, possui o maior percentual de crianças em idade escolar. No entanto, ao se comparar as pessoas matriculadas frente à população já em idade escolar, é possível observar a carência de creches na região (Figuras 2 e 3).

De outro lado, no Norte, temos tam- 


\section{Comparação de desempenho no IDEB (Ensino Médio)}

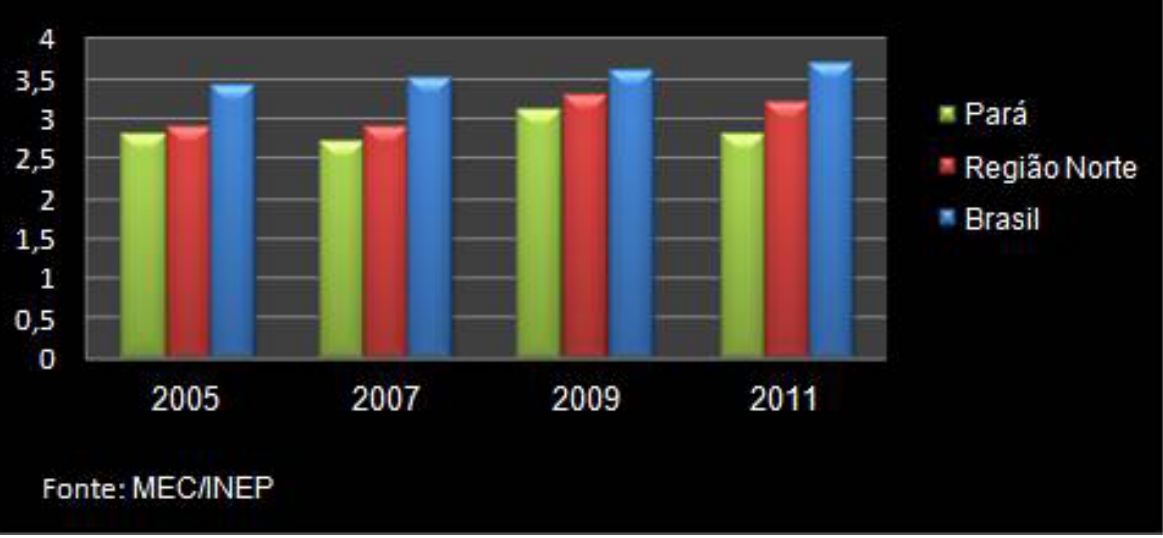

Figura 1 - Comparação entre Pará, região Norte e Brasil com relação ao desempenho no IDEB.

bém o maior número de crianças por turma (Tabela 1).

A tabela 1 explicita que os números de crianças por turma na creche e pré-escola revelam uma sobrecarga significativa, quando comparados à média nacional.

Comparada com outros níveis de ensino, a educação infantil ainda tem baixa demanda atendida, segundo o Censo de 2010, com uma média nacional de 29,3 matrículas em escola ou creche na rede municipal e estadual, para cada 100 crianças de 0 a 5 anos de idade. A demanda atendida é mais baixa em alguns Estados brasileiros, dentre eles o Amapá $(20,0)$ e o Amazonas (22,9). O referido censo revela ainda que estes níveis educacionais abarcam os mais elevados percentuais de atendimento pela rede pública de ensino na região Norte. Ou seja, a população da região Norte depende dos serviços públicos para que sejam atendidas as necessidades de suas crianças, numa etapa da vida considerada crucial para o desenvolvimento pleno de competências e habilidades. Na Amazônia, como em todo o País, esta etapa da educação vem sendo negligenciada, particularmente na etapa de 0 a 3 anos. Estudos (Alves 2007) apontam que só a partir de 1987 passos iniciais foram dados no sentido de investir na formação de professores e na sua condição profissional e, a partir de 1997, novos espaços mais estruturados são criados em Belém. Souza (2007) aponta que se pode identificar numa importante iniciativa levada a cabo em Belém, a Escola Cabana, sinais de boas possibilidades de um trabalho produtivo e eficiente na região, no campo da educação infantil. Enfim, o cenário mostra que a educação infantil e, como veremos adiante, o ensino médio, constituem os grandes desafios 


\section{$\%$ das pessoas matriculadas}

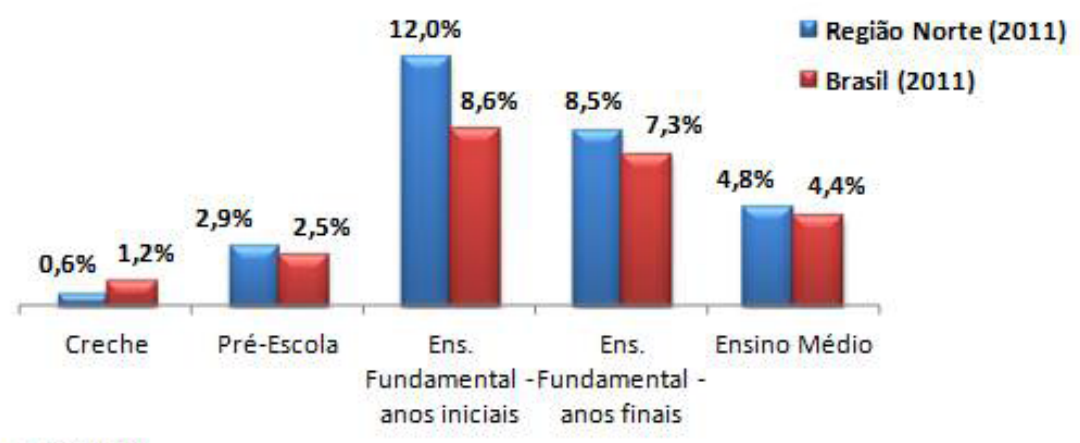

Fonte: MEC/INEP

Figura 2 - Comparação entre a região Norte e o país com relação à proporção de matriculados nos diferentes níveis escolares.

\section{$\%$ das pessoas em idade escolar}

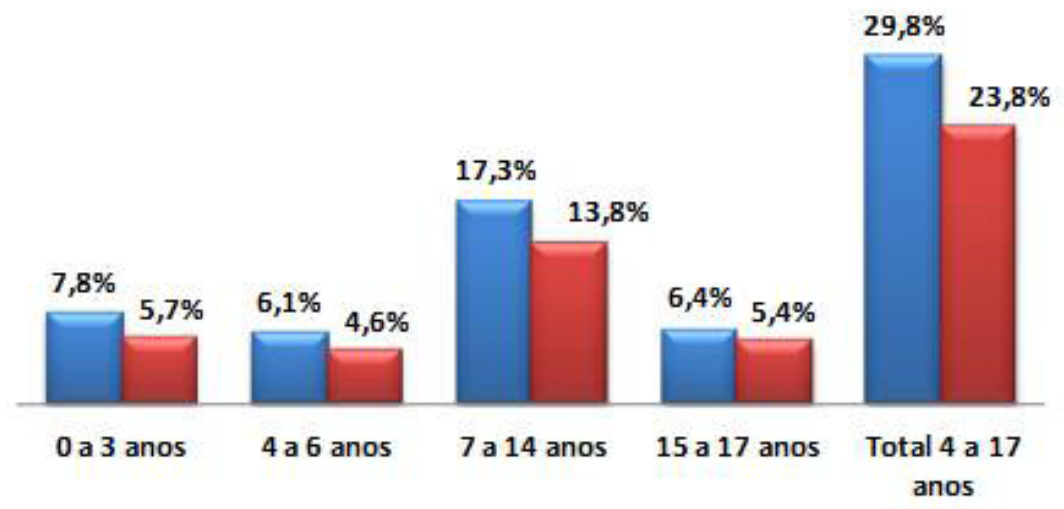

Fonte: IBGE

I Região Norte (2010) ㅂrasil (2010)

Figura 3 - Comparação entre a região Norte e o país com relação à proporção de pessoas em idade escolar. 
Tabela 1

Média de alunos por turma

\begin{tabular}{l|c|c|c|c|c}
\hline $\begin{array}{c}\text { Média de } \\
\text { alunos por } \\
\text { turma e } \\
\text { horas }\end{array}$ & Creche & Pré-Escola & $\begin{array}{c}\text { Ensino } \\
\text { Fundamental: } \\
\text { anos iniciais }\end{array}$ & $\begin{array}{c}\text { Ensino } \\
\text { Fundamental: } \\
\text { anos finais }\end{array}$ & $\begin{array}{c}\text { Ensino } \\
\text { Médio }\end{array}$ \\
\hline $\begin{array}{l}\text { Região } \\
\begin{array}{l}\text { Norte } \\
(2010)\end{array}\end{array}$ & 20,9 & 21,2 & 29,6 & 28,7 & 31,8 \\
\hline Brasil (2010) & 15,5 & 19,1 & 24,6 & 29,0 & 32,4 \\
\hline
\end{tabular}

Fonte: MEC/ INEP/ DTDIE

a serem enfrentados pelo poder público em todo o Brasil e particularmente na região Norte nos próximos anos.

\section{APONTAMENTOS SOBRE A HISTÓRIA DA EDUCAÇÃO NA REGIÃO NORTE}

$\mathrm{Na}$ região Norte, como em outras regiões do Brasil, as primeiras experiências pedagógicas nasceram dos religiosos, objetivando catequizar os índios; ao mesmo tempo em que aumentaram o poder dos missionários e fortaleceram o modelo colonizador. O que se pode constatar é que se tratava muito mais de catequização e instrução do que propriamente de educação, no sentido escolar que se aplica ao termo (Colares 2011). A escola (no sentido de local de ensino e aprendizado dos códigos da escrita e da leitura) não aparecia como instituição desejada ou mesmo necessária, embora a educação (no sentido de socialização e de aceitações de padrões que interessavam ao colonizador) fosse valorizada. Aos religiosos cabia a tarefa educativa, seja através de escolas ou de outros meios. Cuidando da conversão do nativo à religião cristã, e introjetando novos costumes através dos aldeamentos, os missionários levavam a cabo o trabalho de catequese e também realizavam a instrução formal. Os jesuítas fundaram o primeiro curso superior regular no ano de 1695 e construíram o Colégio Santo Alexandre, primeiro colégio da Amazônia, onde eram administradas aulas nos níveis primário, secundário e superior. Este último conferia aos alunos o diploma de Bacharel, Licenciado e Mestre em Artes, não obstante o curso se voltasse para a formação de novos religiosos. O ensino público da capitania do Grão-Pará foi regulamentado em 1799, quando Belém passou a contar com duas escolas primárias e três escolas de humanidades, e outras 13 escolas foram criadas no interior. Analisando o número e o tipo de escolas regulamentadas em Belém, Vianna (1987) faz o seguinte comentário “ $h a-$ via mais quem estudasse latim, philosophia, mathematica, do que quem precisasse das luzes do A B C' (Colares 2011). 
Já naquele período, a situação da educação na região Norte evidenciava o paradigma da desigualdade percebido em diversas instâncias da vida social brasileira.

Alguns autores (Nery, Souza e Oliveira 2007) destacam que, observando a história do Pará, por volta de 1850, pode-se encontrar um acontecimento marcante, que acabou se constituindo num ponto de partida para os rumos que tomou a educação rural na região. Referem-se a uma situação em que mais de 35.000 homens perderam suas vidas nas lutas da Cabanagem (18331835), o que deixou a sociedade arrasada, com núcleos familiares destruídos, gerando como consequência imediata a falta de mão de obra para o trabalho e um conjunto significativo de pessoas marginalizadas em situação de grande dificuldade para sobreviver. A revolução Cabana ou Cabanagem foi parte do movimento nativista vivenciado no Brasil como forma de resistência ao processo de colonização imposto pelos portugueses. No Pará, foi considerado o momento de maior resistência do povo, envolvendo negros, índios e segmentos oprimidos. No entanto, o fim do levante resultou na morte de significativo contingente da população local, particularmente homens - 1/3 da população total (Di Paolo 1986).

Este cenário parece ter impulsionado um dos primeiros projetos para recuperar a economia no sentido de construção de escolas de aprendizes para juntar os órfãos, os desvalidos, os abandonados, os "vagabundos", buscando oferecer não só uma formação ocupacional, como também preparar mão de obra para as tarefas urgentes de alavancar uma economia em estágio crítico. O referido acontecimento no Pará é visto por diferentes autores como algo que trouxe consequências para a forma como a educação foi concebida e engendrada na região (Nery, Souza e Oliveira 2007).

De qualquer forma, cabe chamar a atenção para o fato de que Belém do Pará e Manaus se constituíram nos dois grandes centros acadêmicos e culturais que durante longo tempo a região conheceu. Assim, por quase um século, desde que foram fundados, apenas dois institutos se ocuparam com a formação de professores em nível médio: o Instituto de Educação do Estado do Pará, em Belém, e o Instituto de Educação do Amazonas, em Manaus. ${ }^{2}$ Os demais Estados (quatro deles foram formados após a Constituinte de 1988) não possuíam instituições dessa natureza. Quase todas as instituições de formação profissional, na área de educação, datam da última década do século XX. O imenso território contou, portanto, com apenas aqueles dois institutos ao longo de quase toda a sua existência como parte do Brasil independente.

O mesmo pode ser dito para a formação em nível superior. A Universidade Federal do Amazonas e a Universidade Federal do Pará foram formadas pela reunião de cursos superiores constituídos em diferentes momentos, na primeira metade do século XX. ${ }^{3}$ As duas instituições conformaram universidades a partir da década de 1950 e pontificaram solitárias como as duas 
únicas instituições federais de ensino superior que ofereciam formação na área de educação até a década de 1980, quando emergiram universidades nas áreas dos antigos territórios. $\mathrm{Na}$ esfera privada, a partir dos anos 70 começam a surgir, pelo menos no Pará, as faculdades isoladas e integradas.

Decorre desse fato a circunstância de que aquelas duas instituições, a que nos referimos inicialmente, e as duas universidades federais apontadas permaneceram sozinhas na condução de processos de formação de professores e demais profissionais da educação em toda a região. Nas demais unidades da federação da região Norte, a formação, quando oferecida, se dava por meio de cursos oferecidos por uma das duas universidades fora de seus campi ${ }^{4}$

Não por outra razão, tanto a Universidade Federal do Amazonas quanto a Universidade Federal do Pará constituíram-se, desde cedo, como universidades multicampi, oferecendo cursos de formação fora de suas sedes, especialmente nos municípios dos Estados em que se situavam. A Universidade Federal do Pará representa um bom exemplo, pois desde a década de 1980 oferece cursos em Altamira, Bragança, Cametá, Castanhal, Marabá e Santarém, entre outros diversos municípios (Oliveira 2006, Gomes 2008). Abaetetuba e Soure constam também entre os pioneiros. Destaca-se a eleição de municípios, não apenas pela localização geográfica e densidade populacional, mas também por interesses políticos e apoios oferecidos pelos governos municipais.
Esse quadro só sofreu alguma alteração a partir de meados da década de 1980 , quando surgiram universidades nas áreas dos antigos territórios, agora alçados à condição de Estados, e com a ampliação da atuação de instituições privadas de ensino superior, no mesmo período. ${ }^{5}$ Antes limitada, a oferta de cursos privados cresceu exponencialmente a partir daquela década aproveitando-se, inclusive, da maior demanda por cursos de licenciatura, ${ }^{6}$ em função do que determinou a Lei de Diretrizes e Bases da Educação.

Não obstante, as duas instituições mais antigas permanecem como polos irradiadores dos parâmetros de formação, posto que parte significativa dos docentes das novas instituições é egressa de uma delas. Daí porque partimos delas, principalmente, para situar o perfil dos cursos de formação de professores.

\section{O ENSINO SUPERIOR7 E A FORMAÇÃO DE PROFESSORES}

Os cursos de licenciatura oferecidos por instituições públicas são caracterizados por uma matriz comum, presente em instituições da mesma natureza, em todo o País. Neles, a formação de professor é entendida como uma formação complementar à formação em uma dada área do conhecimento. A licenciatura é vista, no mais das vezes, como um apêndice, um acréscimo de competência que não interfere na natureza profissional do egresso. Isto pode ser percebido nas estruturas curriculares dos diversos cursos de licenciatura e da própria conformação das instituições 
federais de ensino, especialmente as universidades: as matrizes curriculares são divididas em dois grandes grupos de disciplinas; um deles, notadamente o maior, é constituído pela área de conhecimento em formação, oferecido pelo curso no qual o aluno se insere; o outro compreende as disciplinas voltadas para a formação do professor, oferecido por outros cursos que não o do aluno.

Nas instituições privadas, de modo geral, ocorre o inverso. Os cursos de licenciatura são demarcados a partir das disciplinas voltadas para a formação pedagógica, enquanto que as demais disciplinas de formação são agregadas a elas, em função da dimensão diminuta do corpo docente.

Podemos fazer aqui uma comparação entre o nível de qualificação de professores da educação básica, do Brasil, da região Norte e do Pará, e observar, conforme o gráfico da figura 4, que no Brasil o percentual de professores com nível superior é aproximadamente 20 pontos maior que o do Pará. De outro lado, se pode constatar que o percentual de professores com apenas o nível médio é muito maior no Norte e, particularmente, no Pará do que no Brasil (Brito 2012).

As razões para essas conformações distintas aguardam análise específica. No entanto, quando se observa a história dos processos de formação de docentes, pode-se identificar uma base frágil, na qual o curso médio oferecido em liceus foi sendo adaptado ao longo do tempo, até a aparição do curso normal. Estudos (GATTI, 2012) revelam que quando, na década de 30 ocorreu a institucionalização das licenciaturas para formar professores para o secundário, a precarização desta situação se tornou mais evidente e recrudesceu fazendo com que perdure

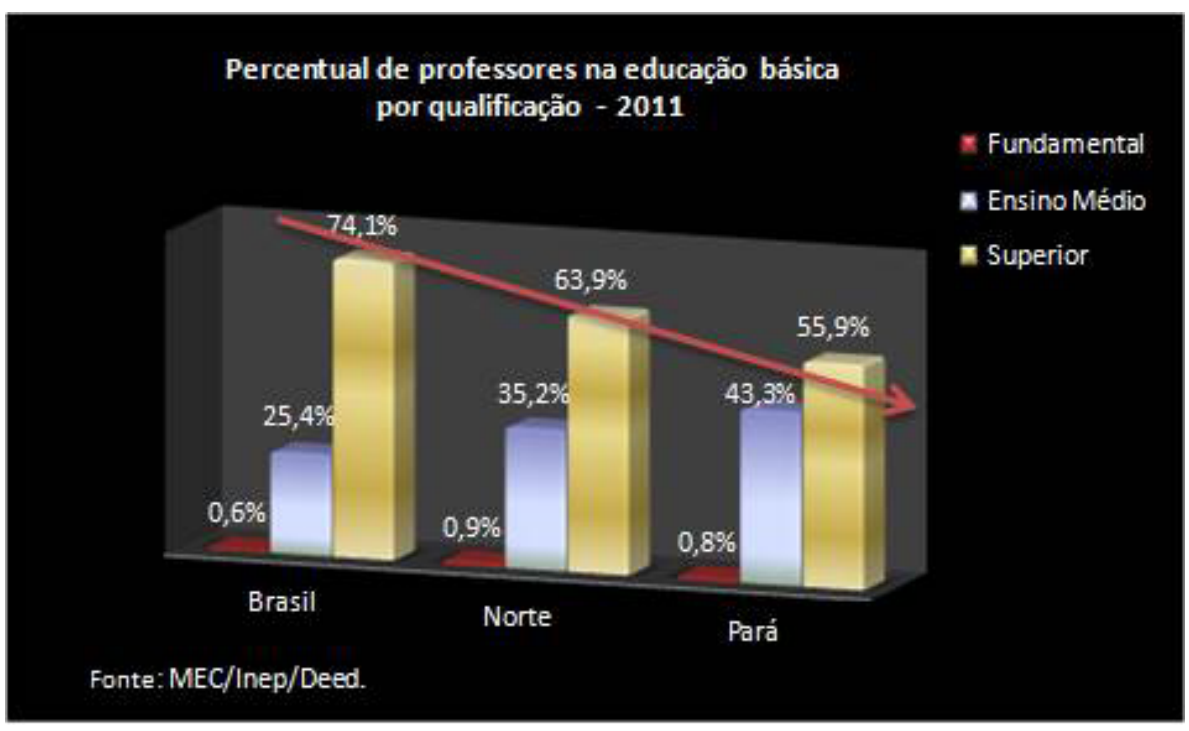

Figura 4 - Proporção de professores na educação básica por qualificação: comparação entre o Brasil, a região Norte e o Estado do Pará. 
até hoje uma maneira de as instituições formadoras funcionarem, tendo sempre em uma instância uma perspectiva formativa genérica e fragmentada e outra com foco em conhecimentos específicos. Embora em diferentes partes do mundo os processos de formação de professores venham sofrendo mudanças, no Brasil isto não vem ocorrendo.

De todo modo, essa não é a característica fundamental da formação oferecida na região. Desde o estabelecimento da exigência legal da formação universitária para o exercício do magistério (BRASIL, 1996), aumentou na região a oferta de cursos modulares, oferecidos tanto por instituições públicas quanto privadas. Decorre daí o fato de que muitos dos professores da rede pública são egressos de uma formação singular: cursos de licenciatura oferecidos por etapas, realizadas nos meses de janeiro, fevereiro e julho; tais cursos são ministrados tanto em polos das instituições públicas ou privadas nos municípios do Estado, quanto em ambientes adaptados para esse fim, como escolas da rede pública; nos quais os alunos cursam uma disciplina por semana, de modo intensivo.

Assim, um contingente significativo de professores da região, detentores de diploma de nível superior, são egressos de cursos de licenciatura dessa natureza. ${ }^{8}$

Cabe lembrar, no entanto, que as experiências com cursos modulares de formação de professores vêm sendo amadurecidas no Pará, já desde os anos 80, e muitos mestres e doutores que compõem atualmente os quadros docentes de universidades públicas locais são oriundos desses cursos de graduação ofertados no interior do Estado.

Em 2011, os percentuais de professores com nível superior atuando na educação básica do Norte e Nordeste foram os mais baixos do Brasil, como se pode observar na figura 5.

Quando se observa os diferentes Estados da região Norte, a situação mais grave é a do Pará (Figura 6).

Por outro lado, vale destacar que, apesar do número de docentes da educação básica com nível superior ser muito pequeno, os que não passaram por esses cursos foram formados por faculdades particulares em condições geralmente muito precárias. Esta discussão aponta para uma importante mudança de foco na formação dos professores na região em uma perspectiva histórica. Enquanto que na década de 1980 buscava-se a formação de nível médio para os professores da educação básica, agora se busca universalizar a formação em nível superior para esses professores. Parece que esforços governamentais em várias áreas, de maneira muitas vezes pontual, descontínua e não monitorada, vêm buscando dar conta do problema crônico de formação de docentes.

Segundo o IPEA (2012), na formação de professores pode-se destacar o Programa de Apoio à Formação Superior em Licenciatura em Educação do Campo (Procampo), que possibilitou a abertura de 3.825 vagas em cursos de licenciatura para a educação do campo, em 31 instituições de ensino superior em todo o País.

Vale ressaltar ainda que, atualmente, 


\section{Professores com nivel superior na educação básica 2011}

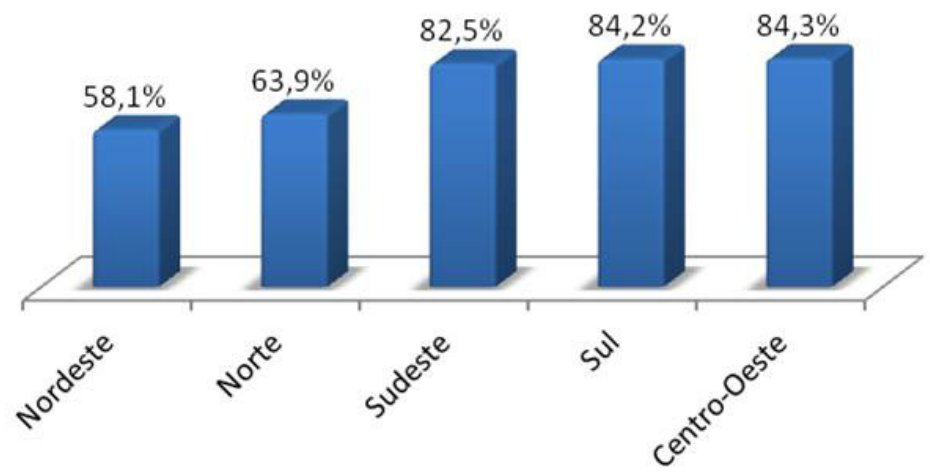

Fonte: MEC/Inep/Deed.

Figura 5 - Proporção de professores na educação básica nas cinco regiões brasileiras (Dados de 2011).

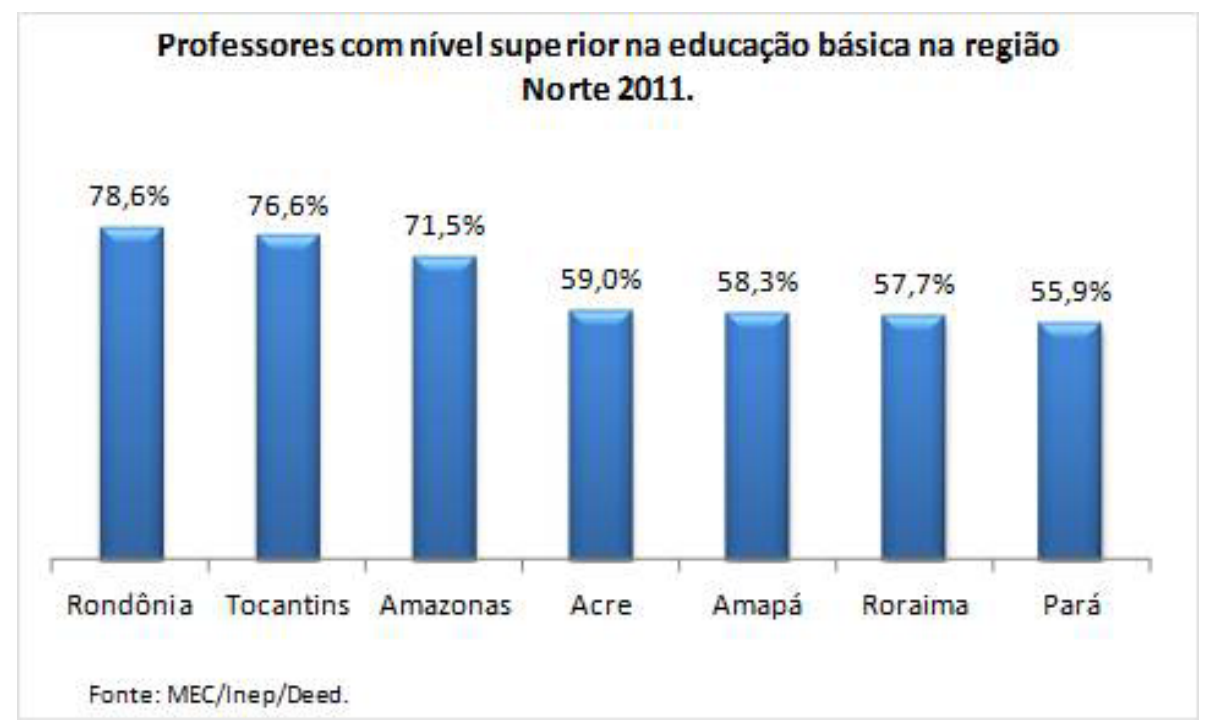

Figura 6 - Proporção de professores com nível superior nos diversos estados da região Norte (Dados de 2011). 
pode-se contar com um amplo programa de formação docente: o PARFOR (Plano Nacional de Formação de Professores da Educação Básica). Este plano, de abrangência nacional, vem sendo citado como uma ação prioritária para a Secretaria de Estado de Educação do Pará, tendo ofertado vagas entre 2009 e 2012, para 26.670 professores-alunos de todos os municípios do Estado, atuando em parceria com todas as Instituições Públicas de Ensino Superior (IPES) do Pará. O PARFOR atua em todas as áreas do conhecimento, ofertando 20 cursos de licenciatura. Os cursos de maior demanda são Pedagogia, Educação Física, Artes e Computação. Cabe salientar ainda que o processo seletivo do PARFOR é diferenciado e o calendário unificado.

Segundo dados da CAPES (Brito 2012), em março de 2012 a região Norte detinha 48\% das 62.685 matrículas nesse programa, seguida da região nordeste com $42 \%$. Das 721 turmas ofertadas na região Norte, 63\% estão no Pará e 21\% no Amazonas. Ou seja, é muito expressiva a participação da região Norte e, em particular, do Pará nesse Plano de Formação. Vale ressaltar que outros Estados brasileiros que possuem demanda por formação inicial de docentes superior à dos Estados da região Norte estão com inserção muito menor nessa estratégia de formação.

\section{EDUCAÇÃO BÁSICA}

Os sistemas de ensino na região Norte, como colocado anteriormente, são centenários. Tanto Belém quanto Manaus possuem estabelecimentos de ensino fundados no século XIX, alguns (poucos) ainda em funcionamento. No entanto, sua característica inicial, demarcada páginas acima, permaneceu constante e conformadora durante longo tempo: Belém e Manaus figuraram solitárias como polos de formação Média e Superior.

Daí por que as duas cidades tornaramse áreas de destino de estudantes de seus Estados e de outros Estados da região. Mesmo hoje, ainda são comuns as iniciativas familiares de enviarem filhos para as cidades de Belém e Manaus para conclusão do ensino médio (Corrêa 1996) e ingresso no ensino superior. Diversas prefeituras de cidades do interior dos Estados do Amazonas e do Pará, principalmente, mantêm casas para acolhimento de seus munícipes adolescentes, transferidos para as capitais a fim de adquirirem a formação necessária (Gonçalvez 2009).

De outro lado, nas pequenas comunidades rurais, os professores enfrentam muitas dificuldades, dentre elas o isolamento, já que as escolas são unidocentes e multisseriadas. $\mathrm{O}$ vínculo que os professores têm com essas escolas, não raro, é fraco, pois grande parte dos profissionais que nelas atuam não é do campo e pode deixar o local de ensino logo que for de seu interesse. Por outro lado, há contraexemplos: professores que residem com suas famílias nessas comunidades, indo apenas uma vez por mês na sede do município para receber salário e fazer pagamentos, cuidando da escola como se fossem seus proprietários, fazendo a merenda, cuidando da limpeza e conservação e revelando forte ligação afetiva com as famílias dos alunos. Aqui, 
como em áreas cruciais da educação no Norte, faltam estudos para evidenciar e quantificar essas duas situações opostas: envolvimento e descompromisso dos professores com as comunidades rurais e ribeirinhas em que atuam.

Neste sentido, a realidade vivenciada pelo professor é difícil e agravada ainda pelo cotidiano de trabalho na escola, como se pode constatar no depoimento abaixo:

"Eu trabalho só num período, de 7 às 11h, com seis séries... todo dia eu levo os cadernos dos menores (Jardim II e III) para casa. Lá eu passo as atividades para eles... aqui eu dou o caderno e depois vou passar as atividades para as $1^{\mathrm{a}}, 2^{\mathrm{a}}, 3^{\mathrm{a}}$ e $4^{\mathrm{a}}$ séries... eu me esforço usando os três quadros... é difícil cumprir os conteúdos, devido serem muitas séries... sinto dificuldade para pôr em prática o planejamento... o tempo que estou explicando para uma, as outras já estão dizendo: 'professora, já acabou minha atividade; a senhora ainda não vem explicar para mim?'. A gente tem que ter aquele fôlego...” (Hage 2008).

Hage tem chamado a atenção para o fato de que, no cotidiano, as políticas de formação não possibilitam que a identidade do professor seja construída como a de um cientista da educação, mas sim como de um tarefeiro, dada a volumosa carga de trabalho e a desqualificação de sua formação.

Há que se reconhecer que, nos últimos anos, se observa uma resignificação da importância dos professores no processo de reforma educacional e o que a realidade tem ensinado é que é preciso desenhar políticas integrais, que envolvam ações para elevar a qualidade da formação inicial e para garantir processos contínuos de formação em serviço, bem como de atenção à carreira docente, que permitam a ascensão na categoria sem ter que sair da escola.

Neste contexto, bastante complexo, a sociedade civil mobilizada vem debatendo soluções locais para fazer frente aos grandes desafios impostos por esta confluência de fatores: grandes distâncias, dificuldades de acesso, limitações no número de escolas e de professores, problemas de gestão e financiamento. Dentro de um intenso diálogo entre poder público e sociedade civil, a experiência dos movimentos Casa Familiar Rural (CFR) e Pedagogia da Alternância é uma das soluções observadas, revelando fragilidades, dificuldades e desafios, mas também propiciando possibilidades de emancipação no processo educacional.

\section{CASA FAMILIAR RURAL E PEDAGOGIA DA ALTERNÂNCIA}

Surgida na França, em 1935, a Pedagogia da Alternância é resultado da insatisfação dos filhos de agricultores com o modelo educacional francês que pouco considerava o meio rural (Wolochen, SouzaLima e Maciel-Lima 2009).

O modelo de alternância foi adotado no Brasil, dentro dos Centros Familiares de Formação por Alternância (CEFFA), tendo formatos diferentes e recebendo denominações diferentes em cada região. No Estado do Pará surge, no início dos anos 90, quando se instalam as primeiras experiências de Pedagogia da Alternância, em 1995, no município de 
Medicilândia, como a Casa Familiar Rural (CFR) e, em 1996, na cidade de Marabá, como a Escola Família Agrícola (EFA). A organização do Movimento dos Trabalhadores Rurais Sem Terra no Pará (MST), a partir de 1994 impulsiona também processos educativos dimensionados pela mesma lógica.

Nas Casas Familiares Rurais, muito frequentemente, encontra-se o modelo de alternância formativa. Os instrumentos pedagógicos são variados, envolvendo Plano de Formação e de Estudos, diferentes tipos de Cadernos de Registros, Viagens de Estudo, Visitas às Famílias e Comunidades, Estágio, Projeto Profissional do Jovem e Avaliação.

A pedagogia da alternância vem sendo entendida como uma necessária educação sistêmica que considera a pessoa nas suas diferentes dimensões, na sua trajetória de vida, no seu meio ambiente; na multiplicidade e diversidade das fontes do saber e seus meios e difusão; que coloca o aprendiz mais como um produtor do seu saber do que como consumidor, como sujeito de sua formação. Há autores que a consideram uma técnica didática que efetiva uma opção política progressista, renovadora e revolucionária (Wolochen, SouzaLima e Maciel-Lima 2009).

Neste contexto, os formadores, denominados monitores, necessitam fazer uma ruptura epistemológica para viver outro sistema pedagógico, outra concepção da aplicação de educação e formação. Também o poder público necessita ser capaz de alterar a concepção de um único sistema hegemônico de educação para todo o País, reconhecen- do os atores sociais locais como importantes vozes para debater e contribuir na definição e construção de conteúdos, materiais e metodologias (op. cit. 2009).

Neste sentido, a oferta de educação básica e superior com os princípios da metodologia da pedagogia da alternância encontra-se dentre as determinações do Decreto n ${ }^{\circ} 7.352 / 2010$, que reconhece a especificidade do campo e de suas populações e preconiza a adaptação da educação a essa realidade.

\section{O DECRETO N ${ }^{\circ} 7.352 / 2010$ E A EDUCAÇÃO NO CAMPO}

A organização do calendário escolar de acordo com o ciclo produtivo e as condições climáticas de cada região, além da oferta de educação básica e superior com os princípios da metodologia da pedagogia da alternância, está prevista no Decreto $n^{\circ} 7.352 / 2010$, que também estabelece para o governo federal o papel de criar e implementar mecanismos que garantam a manutenção e o desenvolvimento da educação do campo nas políticas públicas educacionais, com o objetivo de superar as defasagens históricas de acesso à educação escolar pelas populações do campo. Entre as ações concretas que cabem à União, segundo o referido decreto, estão: fomentar a oferta de alfabetização e da EJA (Educação de Jovens e Adultos) nas localidades onde vivem e trabalham as populações do campo; garantir o fornecimento de energia elétrica, água potável e saneamento básico, bem como outras condições necessárias ao funcionamento das es- 
colas do campo; além de contribuir para a inclusão digital destas escolas.

Até a atualidade, a atuação do MEC aponta-se o Programa Escola Ativa e o Procampo, (IPEA 2012) dentre outras - tem se revelado insuficiente frente às dificuldades que enfrenta a educação do campo e diante da existência de significativa desigualdade nos indicadores educacionais, quando comparadas à população rural e a urbana.

Outro desafio a ser enfrentado que se explicita cada vez mais é o processo acelerado de fechamento de escolas no meio rural brasileiro. Como colocamos anteriormente, o Estado campeão no fechamento de escolas no meio rural fica na região Norte: Rondônia fechou 1.233 escolas, o que equivale a uma diminuição de $63,1 \%$ no número de escolas rurais, em 2010, em relação a 2002. Tocantins também fechou mais de $40 \%$ de suas escolas rurais no mesmo período. No caminho inverso estão Estados que abriram novas escolas do campo: Amazonas, com mais 7,2\%; Amapá, com mais 6,6\%. O Acre manteve o número praticamente igual de escolas no meio rural. Chama a atenção o fato de que entre 2009 e 2010 nada menos que 3.630 escolas do campo foram fechadas em todo o Brasil (IPEA 2012: 145-154). Em termos percentuais, em 2002 as escolas do campo representavam mais da metade de todas as escolas de ensino básico brasileiras, 50,2\%. Em 2010, esse número diminuiu para 39,7\% (IPEA 2012).

O fechamento acelerado de escolas no meio rural do Norte é especialmente preocupante, pois é no campo da referida região que estão os maiores problemas de acesso à educação e onde se evidenciam os piores indicadores.

Com certeza, é urgente a realização de estudos que analisem as particularidades das escolas do campo, principalmente no que tange às casas familiares rurais, cujas dimensões estruturais são precárias, a despeito de guardarem um potencial de profunda transformação, podendo ser analisadas tanto do ponto de vista histórico quanto dos impactos que vêm acarretando para os sistemas de ensino.

\section{DA POLÍTICA DE INTERIORIZAÇÃO}

$\mathrm{Na}$ região Norte, a política de Interiorização (oferta da educação nas localidades do interior do Estado) foi constante, especialmente no Estado do Pará. Por meio dela, o poder público pretendeu garantir o acesso à educação aos cidadãos em todas as localidades do Estado. O maior empecilho foi, como colocado anteriormente, a falta de professores qualificados nos diversos municípios. A questão é relevante. Vários municípios são constituídos por imensas áreas rurais, cujas distâncias não são servidas por sistemas de transporte seguro ou regular. Em muitas dessas localidades, o acesso se dá, quase que exclusivamente, por vias fluviais. $\mathrm{Ne}$ las, o número de crianças e adolescentes em idade escolar é inconstante, em função de diversos fatores. ${ }^{10}$

Capitais e grandes municípios: há oferta regular de todos os níveis de ensino da Educação Básica, promovida pelas redes pública e privada de ensino; as escolas e as turmas seguem os padrões comuns de demais cidades de mesmo porte - há 
oferta de todos os níveis de ensino, em turmas divididas em séries/anos de ensino e professores graduados;

Demais municípios: há oferta desigual dos níveis de ensino - as escolas não se distribuem de modo uniforme pelas áreas dos municípios e, em grande parte deles, há pouca oferta de escolas de Ensino Médio; a educação pública é preponderante; turmas reunindo alunos de séries/ anos diferentes são comuns (Lima 2009, Barros 2006); há até pouco tempo os cursos intervalares também eram parte da política educacional oferecida em alguns destes Estados, especialmente para o Ensino Médio, nos mesmos termos dos cursos modulares oferecidos em nível superior; grande parte do corpo de professores não possui graduação alguma ou não possui graduação na área de ensino na qual atua; muitos professores atuam em diversas áreas do conhecimento diante do imperativo de cumprir a carga horária estabelecida; por fim, o quadro docente em boa parte dos municípios não é efetivo ou regular, de modo que a maior parte dos professores possui contrato temporário, muitas vezes em função de interesses políticos.

Neste contexto, merece uma breve abordagem o Sistema de Oferta Modular de Ensino (SOME), que realiza a oferta de ensino nas comunidades rurais e ribeirinhas do Pará. Trata-se de sistema direcionado às regiões mais longínquas do Estado onde não existem os ensinos fundamental e médio. Em 2012, este sistema esteve presente em 450 localidades de 98 municípios paraenses, possuindo em média um quadro de 1.377 professores (990 efetivos e 387 temporários) para atender aproximadamente 33.081 alunos (Brito 2012).

\section{EVASÃO OU EXPULSÃO?}

Fúlvia Rosemberg (1985) propõe a substituição do termo evasão por expulsão, quando o sistema de ensino não cria condições estruturais para a permanência da criança e do adolescente, e não os acolhe verdadeiramente em sua singularidade cultural. Dessa forma, não é a criança ou adolescente que evade, mas o sistema que o expulsa. Em 2010, a região Norte foi a que apresentou o mais elevado percentual de pessoas que não frequentavam escola, na faixa etária de 6 a 14 anos, tanto em área urbana como rural (IBGE, Censo 2010), ${ }^{11}$ embora o problema esteja presente em outras regiões do País. De fato, permanecer na escola tem sido um dos grandes desafios da situação educacional de crianças e adolescentes. No quadro a seguir, podemos observar os níveis de abandono, aprovação e reprovação escolar no ensino médio da região Norte e Pará.

O índice de abandono no Estado do Pará é quase o dobro do índice do Brasil. Os jovens que abandonaram a escola sem completar o ensino médio tornaram-se o problema mais grave a ser enfrentado pela política educacional e, nesse contexto, tanto o atraso escolar no ensino médio quanto o abandono escolar precoce são indicadores extremamente relevantes para retratar a vulnerabilidade atual e futura destes jovens.

A repetência e o abandono escolar vão conformando uma realidade de distorção da idade-série que ganha contornos 
graves no ensino médio, como se pode observar no gráfico da figura 7.

$\mathrm{O}$ percurso de repetências que gera a chamada distorção idade-série tem sido considerado uma forte razão para o abandono. A média nacional da taxa de distorção entre idade e série em 2010, no Ensino Médio era de 34,5\%, porém, na região Norte era de 50\%. Baixa qualificação dos professores, instalações precárias, transporte inadequado e falta de material pedagógico relacionado à cultura local vêm sendo apontados como alguns dos fatores responsáveis por diminuir o interesse dos estudantes nas aulas e, consequentemente, por retê-los ao longo

Quadro 1

Indicadores de Rendimento Escolar

Ensino Médio

Taxas de Aprovação, Reprovação e Abandono, segundo a Região Geográfica e a Unidade da Federação - 2011

\begin{tabular}{l|c|c|c}
\hline \multirow{2}{*}{$\begin{array}{c}\text { Unidade da } \\
\text { Federação }\end{array}$} & \multicolumn{3}{|c}{ Ensino Médio - Taxas de Rendimento Escolar } \\
\cline { 2 - 4 } & Aprovação & Reprovação & Abandono \\
\hline Brasil & 77,4 & 13,1 & 9,5 \\
\hline Norte & 75.4 & 10,7 & 13,9 \\
\hline Pará & 69,9 & 12,4 & 17,7 \\
\hline
\end{tabular}

Fonte: MEC/INEP/Deed.

\section{Taxa de distorção idade-série}

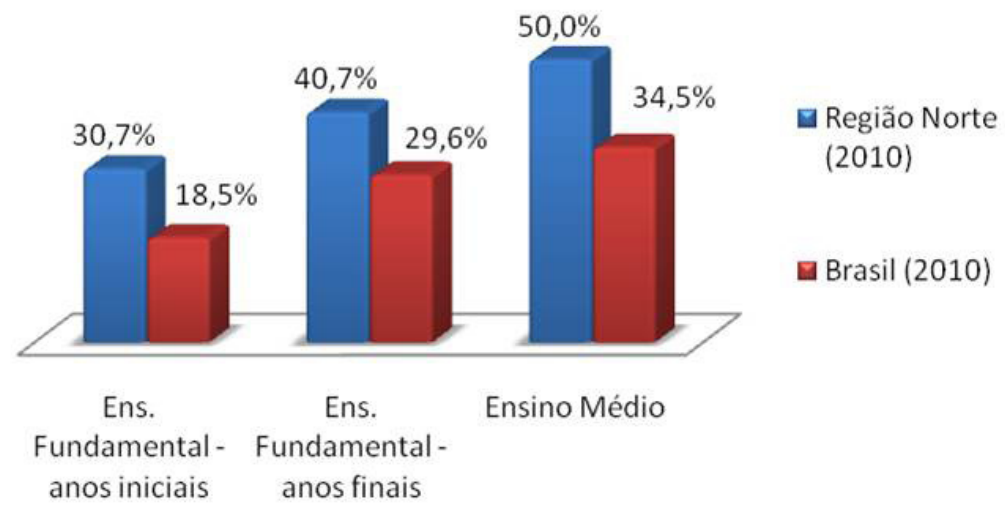

Fonte: MEC/INEP/DTDIE

Figura 7 - Taxa de distorção idade/série: comparação entre a região Norte e o Brasil (Dados de 2010). 
do ensino fundamental, impedindo que avancem para o ensino médio.

É importante ressaltar aqui que o ensino médio se configura como uma etapa crucial da trajetória escolar, e os dados acima podem estar revelando as deficiências acumuladas desde o início do processo de escolarização. $\mathrm{Na}$ educação básica, esse nível de ensino se constitui como um dos principais desafios de inclusão para a efetivação do direito à educação, considerando-se sua obrigatoriedade progressiva. ${ }^{12}$

Cumpre ressaltar que a carência desse nível educacional pode levar à inserção precária no mercado de trabalho e a maiores riscos de exclusão social. Neste sentido, um estudo da Organização para a Cooperação e o Desenvolvimento Econômico $^{13}$ reafirma a maior vulnerabilidade dos jovens que não concluíram o ensino médio com relação ao acesso às oportunidades de qualificação adicional e de emprego estável. Eles experimentam maiores chances de desemprego ou de desemprego de longo prazo e por períodos recorrentes. Também sofrem com empregos instáveis, inseguros e de baixa remuneração. Segundo dados do Censo Demográfico de 2010, os 20 municípios com as menores taxas de frequência líquida no ensino médio estavam majoritariamente no Pará. Há municípios no Amapá e no Acre que também fazem parte desse grupo.

A questão que se coloca é como a escola que temos hoje pode ser um espaço de permanência para crianças e adolescentes, dialogando com a sua cultura, necessidades, expectativas e condições de vida, e, ao mesmo tempo, ser uma escola capaz de prepará-los para atender às exigências escolares e profissionais futuras?

Dentre os principais motivos para a não permanência na escola, durante o ensino médio, está o ingresso no mercado de trabalho. Cabe ressaltar, ainda, que nos últimos anos houve redução do trabalho infantil em todas as regiões do Brasil, exceto na Norte.

Em 2011, havia no Brasil cerca de 3,7 milhões de trabalhadores de 5 a 17 anos de idade; em dois anos houve redução de 14,0\% neste índice. Esta queda se deu em todas as regiões, exceto na região Norte. Assim, as regiões Norte $(10,8 \%)$ e Sul $(10,6 \%)$ apresentaram em 2011 os maiores níveis de ocupação no trabalho, entre crianças e adolescentes (IBGE - PNAD 2011)..$^{14}$

Por outro lado, estudos (Unicef 2011) vêm destacando que em todo o Brasil existem outras condições que impedem a permanência na escola. A pobreza e a pobreza extrema, a exploração no trabalho, a privação da convivência familiar e comunitária, os homicídios, a gravidez na adolescência, as doenças sexualmente transmissíveis, especialmente a AIDS, o abuso e a exploração sexual e o abuso de drogas têm forte impacto no percentual de adolescentes que abandonam a escola. Diante deste grave quadro nacional, os adolescentes que vivem na Amazônia estão entre aqueles que têm seus direitos mais violados no dia a dia, e isto pode ser visto por índices, tais como a taxa de homicídio entre adolescentes (22\%), que é superior à média nacional $(19 \%$ do total), ou o percentual de meninas que têm filhos nesta etapa da vida, na região Norte, que é quase o dobro da média nacional (op. cit.). 
No que diz respeito às populações rurais, negras e indígenas, as desigualdades são ainda mais expressivas, revelando problemas mais complexos relacionados à gestão educacional, à insuficiência e inadequação do transporte escolar, à baixa qualidade da formação dos profissionais de educação e à carência de estrutura física e de currículo e material didático voltado para a cultura da região, à baixa observância da Lei de Diretrizes e Bases alterada pela Lei no 10.639/03 e pela Lei no 11.645/08 (História e Cultura Afro-Brasileira e Indígena), entre outros. Neste sentido, tendo em vista a singularidade e a situação mais agravada em termos de desigualdades, faremos uma breve abordagem sobre a educação indígena e a educação quilombola.

\section{POLÍTICAS PÚBLICAS COM RECONHECIMENTO DE IDENTIDADES - EDUCAÇÃO INDÍGENA E EDUCAÇÃO QUILOMBOLA}

\section{EDUCAÇÃO INDÍGENA}

A região Norte contempla o maior contingente populacional de povos indígenas do Brasil: a terra com maior população indígena é Yanomami, no Amazonas e em Roraima, com 25,7 mil indígenas. O Censo de 2010 registrou no Brasil 896,9 mil indígenas, em 505 territórios que representam 12,5\% do território brasileiro. Foram encontradas 305 etnias que falam 274 línguas indígenas (IBGE 2010).

Mesmo com uma taxa de alfabetização mais alta que em 2000, a população indígena ainda tem nível educacional mais baixo que o da população não indígena, especialmente na área rural. $\mathrm{O}$ analfabetismo chega a $33,4 \%$ para os indígenas de 15 anos ou mais em áreas rurais e, segundo o censo de 2010, a educação de jovens e adultos tem entre os indígenas 246.793 matrículas (IBGE 2010).

A questão da educação indígena é complexa. O que consideramos educação indígena pode ser entendido de duas formas - a educação indígena a ser oferecida aos povos indígenas e o conteúdo de História Indígena oferecido para todo o Brasil, conforme determina a Lei de Diretrizes e Bases da Educação (Brasil 2008). Concentraremo-nos, aqui, no primeiro caso, mas algumas considerações sobre o segundo são importantes, uma vez que ambos estão inter-relacionados.

Ainda que os livros didáticos distribuídos a partir do Programa Nacional do Livro Didático incluam algum conteúdo relativo à História dos Povos Indígenas, duas questões devem ser objeto de reflexão e atenção: em primeiro lugar, os livros didáticos distribuídos por aquele programa ainda restringem a abordagem sobre a experiência indígena ao passado colonial, desconsiderando a participação indígena nos processos históricos ocorridos desde a Independência; em segundo lugar, os cursos de formação de professores frequentemente minimizam o conteúdo relacionado à temática indígena e, amiúde, assumem uma postura paternalista diante da questão, comprometendo as atitudes dos futuros professores diante do tema e, consequentemente, diante dos futuros alunos (Coelho 2010a, 2010b).

No que tange à educação indígena 
(oferecida aos povos indígenas), encontramos situações diversas na região: em alguns Estados, como Amazonas e Roraima, há políticas educacionais voltadas para os povos indígenas que contam com sua participação na formulação e implementação; nos demais Estados, a política é desigual, por razões diversas, e a aplicação é significativamente menos bem conduzida que naqueles dois primeiros.

No Amazonas e em Roraima contamse mais de mil escolas, considerando-se que em toda a região há 1.469 escolas. $^{15}$ Naqueles dois Estados, parte dos professores e dos agentes escolares é indígena e oferece uma educação bilíngue e direcionada a partir das políticas educacionais indígenas (Melia 1999; Silva 1999, 2000; Weigel 2003; Cunha 2008; Baines 2012). Nos demais Estados, os dados disponíveis são limitados. O contato com professores da rede municipal de diversas regiões do Estado do Pará nos permite afirmar que, nesse Estado nem todas as escolas indígenas oferecem uma educação bilíngue. Aliás, alguns dos alunos dos cursos de formação de professores atuavam em aldeias indígenas sem qualquer conhecimento das línguas indígenas ou qualquer qualificação para o exercício da profissão junto àqueles grupos - tratavase de professores leigos, sem a formação mínima exigida por lei para a atuação como educadores em qualquer sistema de ensino. Vale salientar que é expressivo o contingente de professores indígenas, $10 \%$ do total, em atuação nessas escolas, os quais não só não concluíram o ensino fundamental como nunca receberam nenhuma formação para atuar como professores. $\mathrm{Na}$ região Norte, $18,4 \%$ dos docentes indígenas têm apenas o ensino fundamental incompleto, o que evidencia a necessidade contínua de investimentos específicos na área. ${ }^{16}$

De qualquer forma, não se encontrou registros de política educacional voltada para os povos indígenas junto à Secretaria de Educação do Pará. ${ }^{17}$

Cabe comentar, no entanto, que vêm sendo oferecidos cursos de licenciatura para jovens indígenas em 20 universidades federais. Cerca de 2 mil docentes já foram formados e 3 mil estão na universidade. A pretensão é formar 12 mil professores indígenas no prazo de seis anos. No currículo, há oito disciplinas: matemática, português, geografia, língua kuikuro, história, ciência, arte e educação física (exercícios da cultura do povo kuikuro) (Unicef 2011:89).

Está em discussão atualmente, no MEC, a organização da educação indígena por territórios etnoeducacionais, conforme critérios sociais e históricos dos povos. Uma Comissão Gestora já foi formada e discute essa divisão junto com os indígenas.

\section{EDUCAÇÃO QUILOMBOLA}

No que se refere à educação quilombola, a região Norte conta com 442 áreas reconhecidas como de antigos quilombos. ${ }^{18}$ Em geral, as terras quilombolas estão em territórios de difícil acesso, onde vive uma população com histórico de resistência à dominação. A Constituição Federal, a Convenção 169 da Organização Internacional do Trabalho, o Decreto $n^{\circ} 4887$, de 2003, e a LDB garantem a essas comu- 
nidades, além da posse e propriedade coletiva da terra, o direito a serviços como saúde, educação e saneamento básico. $\mathrm{O}$ primeiro Censo Escolar que incluiu as comunidades quilombolas foi realizado apenas em 2004. Por si só, este dado revela uma relevante razão para a carência de dados que se observa na região. De qualquer forma, segundo o Censo Escolar, 50,9\% das 1.253 escolas em comunidades remanescentes de quilombos no Brasil estavam nos Estados da Amazônia Legal (Unicef 2011:92).

Nos sites do MEC e do INEP, não se encontram dados atualizados sobre a educação quilombola, mas até 2007 houve um crescimento significativo no número de matrículas em todos os níveis, com destaque para a pré-escola $(282 \%)$ e o ensino fundamental $(166 \%)$. O menor aumento ocorreu no ensino médio (18\%).

Somente 148 alunos cursavam o ensino médio em escolas quilombolas na Amazônia, o que mostra a dificuldade dos meninos e das meninas dessas comunidades em concluir os estudos no campo (op. cit.). A educação de jovens e adultos, no entanto, tem dentre os quilombolas 210.485 estudantes matriculados, segundo censo de 2010.

Os dados relativos à quantidade de escolas algumas vezes são desencontrados. De todo modo, oferecemos o que consideramos ser mais confiável diante do quadro geral que se apresenta.

Condições socioeconômicas desfavoráveis e baixa escolaridade dos pais e professores podem dificultar a aprendizagem de meninas e meninos quilombolas. Neste sentido, importa observar que
$57,5 \%$ das crianças e dos adolescentes quilombolas do País pertencem a famílias da classe E.

Nas comunidades remanescentes de quilombos da Amazônia, 15\% dos docentes tinham ensino superior, sendo que $73 \%$ concluíram apenas o ensino médio, segundo o Censo. $\mathrm{O}$ índice distancia-se de maneira alarmante, quando comparado ao das escolas não quilombolas da região - de $54 \%$ e $45 \%$, respectivamente (Unicef 2011: 89).

A condição precária das escolas, nas mesmas comunidades, salta aos olhos: $77 \%$ das instituições não tinham rede de esgoto; $74 \%$ não contavam com energia elétrica e 12\% não disponibilizavam água filtrada para os alunos. Em sete escolas, o abastecimento de água nem sequer acontecia (mesmo por meio de poços, rios ou cisternas) (op. cit.).

Outra dificuldade dos alunos quilombolas é estabelecer vínculos entre os conteúdos aprendidos na escola com a vida no dia a dia da comunidade. O artigo $26 \mathrm{da}$ LDB obriga que os currículos dos ensinos fundamental e médio tenham uma base nacional comum, "a ser complementada, em cada sistema de ensino e estabelecimento escolar, por uma parte diversificada, exigida pelas características regionais e locais da sociedade, da cultura, da economia e da clientela", e a LDB alterada pela Lei $n^{\circ} 10.639$, obriga o ensino da história e da cultura afro-brasileiras.

No entanto, apenas 11\% das escolas quilombolas da Amazônia utilizavam material didático relacionado ao contexto e cultura negra. Entende-se que deste cenário pode decorrer a perda de in- 
teresse pelas aulas, bem como a desvalorização da cultura tradicional dos quilombos transmitida oralmente de geração a geração.

Neste sentido, a educação oferecida revela questões análogas à educação indígena. As políticas voltadas para as populações quilombolas não podem ser dissociadas das iniciativas de inclusão de antigos agentes sociais desconsiderados pelo conteúdo curricular durante longo tempo, conforme determina a Lei $\mathrm{n}^{\circ}$ 10.639/03. ${ }^{19}$ Nas escolas da região Norte os projetos desenvolvidos com vistas à execução da referida lei, a despeito dos avanços dos últimos anos, ainda padecem das lacunas provenientes da formação docente, a qual nem sempre contempla as temáticas arroladas pela lei ou o instrumental teórico necessário para enfrentá-las.

Ainda no que tange à educação quilombola, a região conta com 213 escolas que atendem 18.135 alunos, distribuídos pelos Estados do Amapá, Pará, Rondônia e Tocantins. ${ }^{20} \mathrm{~A}$ constatação da existência das escolas, no entanto, não significa a existência de políticas educacionais voltadas para essa modalidade. A considerar as páginas mantidas pelas Secretarias de Educação, o quadro é desalentador: não há menção de projetos ou políticas específicas para os Estados do Acre, do Amapá, Amazonas, Rondônia, Roraima e Tocantins. Para o Estado do Pará, um único projeto em vigor, voltado para a qualificação de professores, em atenção à Lei no 10.639/03, ${ }^{21}$ intitulado "Educação, Etnicidade e Desenvolvimento: Fortalecimento de Negros e Negras Quilombolas na Educação Básica”. ${ }^{22}$ No entanto, não localizamos o projeto, de forma a considerá-lo detidamente.

Não obstante, identificamos a existência de alguns projetos em andamento na região, ainda que não tenha sido possível localizá-los: Rondônia possui um curso de capacitação de professores de áreas quilombolas (2011); ;3 já no Tocantins registra-se a elaboração do plano estadual de educação para as relações étnico-raciais. ${ }^{24}$ Por outro lado, assim como se observa no caso da educação indígena, nos últimos anos o Censo Escolar tem registrado uma evolução da oferta educacional nas comunidades quilombolas, mas que ainda é muito pequena considerandose a gravidade do quadro. Programas e políticas, tais como Brasil Quilombola e Programa Territórios da Cidadania, com recursos específicos para a educação quilombola, investidos nos municípios, buscam a melhoria das condições da educação.

Para ampliar o acesso dos alunos quilombolas à educação, se observa ações voltadas à formação e à capacitação de professores, à ampliação e à melhoria da estrutura física das escolas e à produção e aquisição de material didático específico para essas comunidades. No âmbito da sociedade civil, destaca-se a atuação da Coordenação Nacional de Articulação das Comunidades Negras Rurais Quilombolas (CONAQ). Criada em 1996, após o I Encontro Nacional de Quilombos, a organização, que representa quilombolas de 22 Estados do Brasil, promove projetos de desenvolvimento sustentável das comunidades e procura garantir o direito de crianças e adolescentes a uma educação que contribua para 
manter a cultura e a tradição quilombolas (Unicef 2011: 28-29).

\section{FORMAÇÃO DE PROFESSORES - EDUCAÇÃO PARA DIVERSIDADE}

Segundo o IPEA (2010), o programa de apoio à formação superior de professores que atuam em escolas indígenas de educação básica (Prolind) beneficiou 1,5 mil professores indígenas em 23 licenciaturas interculturais criadas em 20 IES. A área de diversidade e cidadania do MEC também trabalha com a formação continuada voltada a professores da educação básica. Em 2010, foram ofertadas 37 mil vagas em cursos de cultura afro-brasileira e indígena, questões de gênero e diversidade nas escolas, meio ambiente e direitos humanos. Os cursos ofertados nas áreas de raça e gênero, em particular, são parte das estratégias voltadas à educação das relações étnico-raciais e de gênero e diversidade na escola. No entanto, não encontramos dados específicos da oferta destes cursos por região.

\section{ENSINO MÉDIO - ALGUNS EXEMPLOS DE POLÍTICAS PÚBLICAS}

Criado em 2009, pelo Ministério da Educação, o projeto Ensino Médio Inovador tem a finalidade de apoiar e promover novas práticas pedagógicas em escolas públicas a partir de uma concepção mais ampla de aprendizagem, marcada pela interdisciplinaridade e a contextualização, num outro esforço de aproximar a escola do projeto de vida dos adolescentes.

Parcerias do MEC com as redes estaduais de educação são estabelecidas para o desenvolvimento de soluções que diversifiquem os currículos com atividades integradoras, a partir de quatro eixos: trabalho, ciência, tecnologia e cultura. O programa objetiva um aumento de carga horária na escola, oferecendo aos alunos a possibilidade de escolher parte desta carga horária. Teoria e prática devem estar associadas, com ênfase em atividades práticas e experimentais, valorização da leitura e garantia de formação cultural aos adolescentes.

O Ensino Médio Inovador serviu de base para as novas Diretrizes Curriculares do En $\neg$ sino Médio, o que pode induzir a um processo de mudança curricular mais amplo em todo o País (Unicef 2011:87).

Assegurar financiamento e buscar aprimorar infraestruturas e ferramentas de mensuração e indução de qualidade são desafios que estas políticas públicas na área da educação buscam vencer.

Outra vertente de políticas públicas para o ensino médio propõe a educação integral, com vistas a aproximar a escola do universo de interesse e de possibilidades dos adolescentes através do programa Mais Educação, do Ministério da Educação. Em 2010, 2,2 milhões de estudantes eram beneficiados pela estratégia que recebeu $\mathrm{R} \$$ 400 milhões, transferidos diretamente para as escolas priorizadas, que são aquelas que têm baixo IDEB (Índice de Desenvolvimento da Educação Básica) e estão localizadas em regiões mais vulneráveis.

O projeto inclui melhoria da infraestrutura das escolas (especialmente as de ensino médio) e um grande esforço no campo da formação e valorização dos profissionais da educação. 


\section{SOCIEDADE CIVIL E A EDUCAÇÃO NO CAMPO}

As transformações que vêm ocorrendo no campo educacional, em diferentes instâncias, no Brasil e na região Norte, são em larga medida impulsionadas pela sociedade civil.

A sociedade civil organizada protagonizou um intenso e amplo debate sobre a educação brasileira nas décadas de 1980, 1990 e 2000 em defesa da redemocratização do País e da sociedade, principalmente com a elaboração e posterior promulgação da Constituição de 1988 e da LDB/1996. Neste processo, um tema vem ganhando corpo no campo das políticas educacionais, apontando eixos de pesquisa nesta área: o reconhecimento da educação de qualidade como direito de todos(as), com destaque para os direitos de vários segmentos - crianças, jovens e idosos, populações indígenas, afrodescendentes, quilombolas, populações do campo, pessoas com deficiência - e sobre o direito de orientação sexual, opção religiosa e política, entre outros.

É nesse contexto que podemos perceber, na região Norte do País, vários coletivos atuando ao longo do tempo, em diferentes locais, pressionando o Estado no sentido de viabilizar uma educação de qualidade, através da realização de encontros, seminários e publicações, dentre outros. Tendo como base a Constituição Federal de 1988, o Estatuto da Criança e do Adolescente, a Lei de Diretrizes e Bases (LDB) e o Plano Nacional de Educação (PNE), bem como resoluções do Conselho Nacional de Educação e normativas diversas que, de diferentes maneiras e níveis, estabelecem obrigações e orientações voltadas para a educação do campo, os grupos se articulam, ampliam a consciência social sobre direitos estabelecidos na legislação e vão provocando avanços. Cabe ressaltar que o principal fato na educação do campo, em 2010, foi a promulgação do Decreto presidencial $\mathrm{n}^{\circ}$ 7.352, que trata da política brasileira de educação do campo e regulamenta o Programa Nacional de Educação na Reforma Agrária (Pronera), executado pelo Instituto Nacional de Colonização e Reforma Agrária (Incra). Como colocamos anteriormente, este decreto reconhece a particularidade do campo e de suas populações e determina a adaptação da educação a essa realidade. Com todas as limitações, o referido decreto pode se transformar em mais um instrumento de pressão por uma educação de qualidade.

Um exemplo da batalha que vem sendo travada foi destacado nos estudos de Oliveira (2010), resgatando a luta por um currículo calcado nos saberes e histórias locais, na qual ficam visíveis os esforços envidados por instâncias como a Articulação Nacional por uma Educação do Campo (que envolve a participação de diferentes movimentos sociais ligados à causa de uma educação sintonizada com a diversidade socioterritorial) que propôs ao governo federal a preparação das Diretrizes Operacionais para a Educação Básica nas Escolas do Campo (DOEBEC).É necessário reconhecer que essas diretrizes de nível nacional são uma conquista política de movimentos sociais do campo e de seus povos ribeirinhos, indígenas, quilombolas etc. Constata-se que o que foi determinado nas leis brasileiras sobre a Educação Básica do Campo 
ainda não se transformou em realidade concreta e não pode alavancar um efetivo processo de mudança estrutural que os territórios do campo e seus povos tanto almejam. No entanto, os movimentos continuam em ação. O Fórum Paraense de Educação do Campo (FPEC), composto por diferentes segmentos dos movimentos sociais, buscou estabelecer um espaço de ação da SEDUC/PA para alterar a realidade da educação. Ressaltese aqui que a SEDUC/PA criou, em 2004, a Coordenadoria de Educação do Campo (CECAM), ${ }^{25}$ por meio da qual foram elaboradas as diretrizes curriculares voltadas para a Educação Básica do Campo na Amazônia Paraense. Vários seminários vêm ocorrendo em Belém/ PA, organizados pelo FPEC e CECAM, e diversos documentos vêm sendo produzidos. Discussões sobre diretrizes curriculares para Educação do Campo na Amazônia estão ocorrendo com maior frequência para observar se as diretrizes estão sendo viabilizadas no cotidiano das políticas públicas da Secretaria.

Pode-se destacar, também, no Pará um trabalho que envolve conferências e encontros regionais e municipais, no sentido de reorientar o currículo de maneira mais geral, direcionado ao ensino fundamental e ao ensino médio como um todo, no interior da SEDUC/PA.

\section{O CURRÍCULO}

Focalizando o currículo, Oliveira (2010) destaca que a perspectiva adotada no Pará é crítica e resignifica o próprio currículo, buscando ultrapassar os limites do campo pedagógico e debatendo o conteúdo cur- ricular em sintonia com outros campos do saber, inclusive, sendo influenciado ainda pelas políticas de desenvolvimento socioterritorial. Neste sentido, vai além da ideia tradicional-burocrática de currículo, cuja concepção é de sistematização neutra de conteúdos universais das diversas disciplinas ministradas nas escolas, ligada somente ao processo formal de ensinoaprendizagem.

Nesta seara, o território é concebido como espaço político de atuação de ribeirinhos, assentados, indígenas, quilombolas etc., cada um desses grupos definindo suas próprias territorialidades que se interconectam, abrindo possibilidades para a diversidade socioterritorial e suas contradições, o que envolve uma interrelação entre ecologia, cultura, economia e justiça social. As diretrizes curriculares, então, são pensadas como produtos de diversos grupos e sujeitos que participam do cenário político do País.

No Pará, este movimento ganhou visibilidade em 2007 e foi chamado de "Movimento de Reorientação Curricular". Como produtos desses seminários foram elaborados diferentes cadernos de textos denominados "Elementos para uma política educacional democrática e de qualidade para todos".

Oliveira (2010) apresenta a interpretação de 07 (sete) diretrizes curriculares a partir dos documentos da SEDUC/PA ${ }^{26}$ :

1. O currículo é uma construção coletiva baseada nas experiências locais e relacionada ao processo de afirmação das identidades culturais;

2. O currículo é difusor da diversidade sociocultural e instrumento de disputa 
hegemônica pela consolidação de uma cultura, no sentido de possibilitar a democracia no que se refere às questões da diversidade cultural e da emancipação social;

3. As propostas curriculares devem promover o desenvolvimento sustentável e estar ligadas às especificidades regionais;

4. O currículo deve estar em sintonia com a realidade educacional concreta das escolas;

5. A diversidade é o foco central na construção de uma cultura curricular;

6. O Projeto Político Pedagógico (PPP) das escolas visa colaborar para a superação dos processos de desigualdade e exclusão, incentivando, para isso, a participação de todos os sujeitos em uma convivência de respeito à diversidade e à biodiversidade;

7. O Projeto Político Pedagógico deve reconhecer às diversidades e diferenças, dado o caráter multicultural da região amazônica.

Os destaques feitos por Oliveira (2010) sobre as orientações curriculares estão em consonância com estudo realizado por Hage (2005), a partir das vozes dos professores, que traz como conclusão:

1. Agendas do contexto social da região necessitam ser abordadas, pois influenciam fortemente as condições da educação, tais como a deterioração das condições de vida dos que moram no campo, que intensifica a migração campo-cidade; a concepção urbanocêntrica de mundo, que tem como pressuposto que o espaço urbano é superior ao campo, possibilita o acesso a todos os bens e serviços públicos, e de que a cidade é o território do desenvolvimento, da tecnologia e do futuro, enquanto o campo é considerado lugar do atraso, da ignorância, da pobreza e da falta de condições mínimas de sobrevivência.

2. É necessário alterar a lógica de organizar tempos e espaços dos professores e dos alunos, em torno dos "conteúdos" definidos em graus, séries, disciplinas, grades, avaliações, recuperações, aprovações ou reprovações.

3. É fundamental a construção coletiva de um currículo que valorize as diferentes saberes, experiências, valores e particularidades culturais das populações do campo da Amazônia.

4. A escola pode constituir-se num centro de desenvolvimento cultural da comunidade, envolvendo a todos, sem exceção: crianças, adolescentes, jovens e adultos, estudantes, pais, lideranças e membros da comunidade nos processos de compartilhamento do conhecimento e de mobilização e participação coletiva na construção de uma sociedade inclusiva, democrática e plural.

5. As escolas multisseriadas são espaços heterogêneos ao reunir grupos com diferenças de série, de sexo, de idade, de interesses, de domínio de conhecimentos, de níveis de aproveitamento etc.

\section{SÍNTESE PRELIMINAR}

A crescente mobilização da sociedade civil e a institucionalização de uma educação de qualidade na Amazônia enfrentam grandes desafios, mas oferecem sinais de que são possíveis avanços qualitativos e significativos no contexto educacional. 
A dificuldade em reunir elementos informativos é uma das questões relevantes a serem destacadas. Para a elaboração deste texto foram consultadas as páginas das secretarias de educação dos Estados e acionados auxiliares para a coleta de dados, junto à Secretaria de Educação do Estado do Pará. Em relação à maioria das secretarias, deparou-se com limitação na oferta de dados sistematizados, bem como no fornecimento de informações mais precisas por parte dos responsáveis. No caso da SEDUC/PA, foram oferecidos (Brito, 2012) diversos diagnósticos que possibilitaram as diferentes análises referentes ao Estado do Pará.

A dificuldade na obtenção dos dados é indicativa do quadro geral da educação na região, especialmente nos dois maiores Estados que a constituem: políticas e programas conduzidos muitas vezes de forma pontual, sem continuidade e por pessoal que nem sempre possui a qualificação devida. Isto não se dá, que fique claro, por falta de pessoal ou de recursos. As universidades dos dois maiores Estados contam com programas de pósgraduação, os quais formam pesquisadores com a qualificação necessária para a formulação e condução de estratégias.

Vale salientar, no entanto, que uma leitura na robusta publicação ${ }^{27}$ das sínteses dos principais estudos produzidos pelo INEP (Instituto Nacional de Estudos e Pesquisas Educacionais Anísio Teixeira) revela que ao longo de sua existência a região Norte foi objeto de diminuta atenção. Considerando que a função do INEP é produzir diagnósticos que orientem a formulação de políticas educacionais pelos órgãos responsáveis, pode-se deduzir que esta região não vem contando, como deveria, com a obrigatória presença do poder público, auxiliando na concepção e implantação de políticas, formuladas a partir da realidade e dos saberes locais.

De qualquer forma, tendo como ponto de partida o IDEB (Índice de Desenvolvimento da Educação Básica), podemos constatar as consequências que o sistema educacional acarreta ao ser constituído por professores leigos, sem a qualificação necessária, muitos deles com dificuldades básicas, herdadas de uma alfabetização precária. Deste modo, o quadro da educação indígena e da educação quilombola apresenta dificuldades mais agudas, frente ao quadro geral da educação na região. Ele possui especificidades, em função das comunidades atendidas: falta de qualificação, falta de políticas e programas continuados, falta de respeito a pressupostos mínimos como conhecimento das línguas indígenas, da memória e da trajetória das comunidades a que se destinam os programas educacionais formulados, entre outros entraves.

Vale destacar, dentre os exemplos positivos, a oferta de educação indígena nos Estados do Amazonas e de Roraima. Talvez neles resida um bom parâmetro para o início da superação das dificuldades.

Este trabalho reiterou a compreensão de que os sistemas educacionais da região Norte requerem análises circunstanciadas sobre as suas diversas dimensões. Elas podem indicar os entraves e os caminhos possíveis para a melhora da oferta de educação na região Norte. Há que se salientar, no entanto, que os processos que vêm sendo articulados 
pelos coletivos da sociedade civil são alvissareiros, apontando para um avanço que beneficia, não só a região, mas todo o País, ao pautar a construção coletiva de uma proposta democrática de educação de qualidade, que considere a diversidade territorial e humana caracterizadora da região, e que focalize a superação das históricas desigualdades, definindo e monitorando o papel do Estado neste contexto.

\section{NOTAS}

${ }^{1}$ www.ibge.gov.br (Censo Demográfico 2010).

2 Sobre o Instituto de Educação do Amazonas não encontramos títulos específicos; sobre o Instituto de Educação do Estado do Pará (IEP) ver Coelho (2009).

3 Sobre a formação das universidades na região Norte, ver <http://www.ufpa.br e http://www.ufam.edu.br>. Para uma análise mais ampla sobre o ensino superior ver: Chaves et al. (2011), Chaves e Lima (2006).

${ }^{4}$ Há poucos trabalhos sobre a História da Educação na região (ver Damasceno 2012; sobre outra perspectiva, ver Colares 2011).

${ }^{5}$ A Universidade Federal do Acre formouse a partir da junção de duas instituições de ensino superior, em 1974; a Universidade Federal do Amapá foi formada em 1990; a Universidade Federal de Rondônia foi criada em 1981; a Universidade Federal de Roraima foi instituída em 1989; a Universidade Federal do Tocantins foi criada em 2000.

${ }^{6}$ Sobre Licenciaturas, ver: Lei n ${ }^{\circ} 11.788$, de 25/09/2008. Resolução CNE/CES n 3, de 02/07/2007. Dispõe sobre conceito de horaaula, e dá outras providências; Resolução.

${ }^{7} \mathrm{CNE} / \mathrm{CP} \mathrm{n}^{\circ} 1$, de 18/02/2002. Institui as Diretrizes Curriculares Nacionais para a Formação de Professores da Educação Básica, em nível superior, Curso de Licenciatura, de Graduação Plena; Portaria n ${ }^{\circ} 1.264$, de 17/10/2008. Ressaltamos um estudo circunstanciado sobre o Amapá: Maués, Oliveira e Costa (2006).

${ }^{8}$ Em relação a este aspecto, há ausência de estudos. Outras questões precisam de aprofundamento: Qual o impacto da formação em nível superior para a alteração da prática docente, posto que muitos professores das redes de ensino só adquirem a formação necessária após anos de experiência docente? Qual é o impacto dos cursos modulares nos diversos municípios da região? Estas são questões importantes para o dimensionamento de políticas públicas.

${ }^{9}$ Ver http://www.prac.ufpb.br/anais/Icbeu_ anais/anais/educacao/projetogaviao.pdf

10 Sobre a Cultura ribeirinha na Amazônia, ver Gonçalves (2011); conf. trabalho infantil e educação inclusiva: Araújo (2005); Agra (2010); ver ainda Agra (2009).

${ }^{11}$ www.ibge.gov.br (Censo 2010).

${ }^{12}$ Emenda Constitucional no ${ }^{\circ}$, de 11 de novembro de 2009.

${ }^{13}$ Organização para a Cooperação e o Desenvolvimento Econômico - OCDE - 2005.

${ }^{14}$ www.ibge.gov.br (PNAD 2011).

${ }^{15}$ Também: http://portal.inep.gov.br/educacao-indigena.

${ }^{16} \mathrm{http}: / /$ portal.inep.gov.br

${ }^{17} \mathrm{Em}$ relação aos demais Estados http:// www.seduc.am.gov.br/pagina__ interna. php?cod=12; Acre: http://www.see.ac.gov. $\mathrm{br} /$ portal/index.php?option $=$ com_cont ent\&view $=$ article $\& i d=557 \&$ ltemid $=290$; Rondônia: http://www.seduc.ro.gov.br/portal/index.php/legislacao.html.

${ }^{18}$ Consultar o seguinte endereço eletrônico: $\quad<$ http://uc.socioambiental. 
org/territ $\% \mathrm{C} 3 \% \mathrm{~B} 3$ rios-de-ocupa $\%$ C 3\% A 7\% C 3\% A 3 o-tradicional/ territ $\% \mathrm{C} 3 \% \mathrm{~B} 3$ rios-remanescentes-dequilombos>.

${ }_{19}$ A Lei $n^{\circ} 10.639 / 03$, que altera a Lei $n^{\circ}$ $9.394 / 96$, estabelece a obrigatoriedade do ensino da "História e Cultura Africana e Afro-Brasileira" na educação básica. A Lei $\mathrm{n}^{\circ} 11.645 / 2008$ acrescentou a obrigatoriedade do ensino da história e cultura indígenas.

${ }^{20}<$ http:// portal.mec.gov.br/index. php?option $=$ com_content\&view $=$ article\&id $=12398$ \&ltemid $=688>$.

${ }^{21}$ Cf. discussão sobre a Lei n ${ }^{\circ} 10.639 / 2003$ na Região Amazônica, em Coelho (2010), Magalhães (2010); outro trabalho relevante sobre Educação no campo na Amazônia: Oliveira (2010).

${ }^{22}$ Consultar o seguinte endereço eletrônico: $<$ http://www.agenciapara.com.br/noticia. asp?id_ver=106951 >.

${ }^{23}$ Consultar o seguinte endereço eletrônico: $<$ http://www.rondonia.ro.gov.br/noticias. asp?id=12097\&tipo $=$ Mais\%20Noticias $>$.

${ }^{24}$ Consultar o seguinte endereço eletrônico: $<$ http://www2.seduc.to.gov.br/seduc/index.php?option $=$ com_content\&view $=$ article \&id=4962:diretoria-de-diversidade-da-seducpromove-o-mes-da-consciencia-negra-noestado\&catid $=38$ : destaques $>$.

${ }^{25}$ Atualmente, esta coordenadoria adota outro nome, a saber: Coordenadoria da Educação do Campo, das Águas e das Florestas - CECAF, pelo fato de, atualmente, algumas comunidades ribeirinhas e extrativistas não se considerarem como sendo do campo e sim das águas ou das florestas.

${ }^{26}$ Oriundo do relatório do "I Seminário de Elaboração de Políticas Públicas para a Educação do Campo do Estado do Pará”: por uma educação do campo paraense, ocorrido em 2008, no Pará.
${ }^{27}$ Estatísticas sobre Educação Escolar Indígena no Brasil. INEP, 2007.

\section{REFERÊNCIAS}

Agra, K.O. 2009. Buscando caminhos à educaşão inclusiva na Amazônia brasileira. Porto Velho: Recensio.

2010. A educação inclusiva na Amazônia brasileira: um caminho a ser percorrido. Acta. Sei. Human. Soe. Sei. 32(1): 31-38.

Alves, L. M. S. A. 2007. Educaşão Infantil e Estudos da Infância na Amarônia. Belém: Edufpa.

ARAÚJO. R. M. L. 2003. O trabalho infantil no Estado do Pará: uma visão panorâmica. Revista ver a Educação 9(1): 31-50.

Baines, S.G. 2012. O movimento político indígena em Roraima: identidades indígenas e nacionais na fronteira Brasil-Guiana. Caderno CRH 25 (64): 33-44.

Barros, O. F. 2006. Trabalho popular em comunidades ribeirinhas e a educação popular na Amazônia, in Anais do Seminário de Educação e Movimentos Sociais, 4, pp. 7-24. Paraíba: PPGE/UFPB.

Brasil. 1996. Lei n ${ }^{\circ}$ 9.394, de 20 de dezembro de 1996. Brasilia: Diário Oficial [da] República Federativa do Brasil. 20 dez. 1996.

2003. Lei no 10.639, de 20 de dezembro de 2003, altera a Lei no 9.394/96. Diário Oficial [da] República Federativa do Brasil. Brasília, Distrito Federal, DF. 10 de jan., 2003.

2008. Lei n ${ }^{\circ} 11.645$ de 10 de março de 2008. Diário Oficial da União, 11 mar. 2008.

Brito, L. P. 2012. SEDUC-PA. Seminário: Desafios da Educação na Amazônia (dados do INEP). São Paulo: Canal Futura.

Chaves, V.L.J.; \& R.N. Lima. 2006. Educação superior brasileira - Pará. Brasilia: Instituto Nacional de Estudos e Pesquisas Educacionais Anísio Teixeira. 
Chaves, V.L.J.; A.M.M.Camargo; E.D.Monte e V.S. Moraes. 2011. A expansão da educação superior no Pará: cenário atual e tendências, in Política de expansão da educasãa superior no Brasil: democratização às avessas, vol. 1, pp. 39-64. Organizado por A. Cabral Neto; V.L.J. Chaves; I.V. Nascimento. São Paulo: Xamã, 2011.

Coelho, M.C. 2010. As populações indígenas no livro didático ou a construção de um agente histórico ausente, in Educação para a diversidade: olhares sobre a educação para as relacooes étnico-raciais., pp. 97-111. Organizado por W.N.B. Coelho \& A.D.T.V. Magalhães. Belo Horizonte: Mazza.

Coelho, M.C., D.S. Camelo, E.A. Sousa \& P.R.C Melo. 2010. O livro didático e as populações indígenas: um estudo sobre as representações formuladas para o Ensino Fundamental, in Raşa, cor e diferença: a escola e a diversidade, pp. 92-103. Organizado por W.N.B. Coelho \& A.D.T.V. Magalhães. Belo Horizonte: Mazza.

Coelho, W.N.B. 2009. A cor ausente: um estudo sobre a presença do negro na formação de professores -1970-1989. Belo Horizonte: Mazza.

2010. A Lei n 10.639/2003 no Ensino Fundamental, in Educação para a diversidade: olhares sobre a educaşão para as relações étnico-raciais, vol. 1, pp. 18-39. Organizado por W.N.B. Coelho \& A.D.T.V. Magalhães. Belo Horizonte: Mazza.

Coelho, W.N.B \& A.D.T.V. Magalhães. 2010. Educação para a diversidade: olhares sobre a educação para as relacõoes étnico-raciais. Belo Horizonte: Mazza.

Coelho, W.N.B \& M. C. Coelho. 2010. Raça, cor e diferenca: a escola e a diversidade. Belo Horizonte: Mazza.

Colaço, T. L. 1999. Incapacidade indígena: tutela religiosa e violação do direito guarani nas Missões Jesuíticas. Curitiba: Juruá.

Colares, A. A. 2011. História da educação na
Amazônia e questões de natureza teóricometodológicas: Críticas e proposições. Revista HISTEDBR On-Line, número especial, outubro: 187-202. Disponível em: http:// www.histedbr.fae.unicamp.br/revista/ edicoes/43e/index.html

Corrêa, P. S. A. 1996. Ensino médio profissionalizante, ciência e técnica: possibilidades e limites. Vol. 2. Belém: Universidade Federal do Pará.

Cristo, A.C.P. 2009. Cartografias na Amazônia rural ribeirinha. 2007. Dissertação de Mestrado. Programa de Pós-Graduação em Educação, Universidade Federal do Pará, Belém/PA.

Cunha, E. 1975. À margem da bistória. São Paulo: Cultrix; Brasilia: Instituto Nacional do Livro.

Cunha, R. B. 2008. Políticas de línguas e educação escolar indígena no Brasil. Educar 32: 143-159;

Damasceno, R. A. F. 1996. Colonização e educação no Grão-Pará: algumas notas críticas. Ver a Educação 2(1): 71-86.

A. 2012. A $2^{a}$ República e a Educasão no Pará. Belém: Açaí.

Di Paolo, P. 1986. Cabanagem: a revolução popular da Amazônia. Belém: CEJUP.

Gatti, B. 2012. Revista Brasileira de Estudos Pedagógicos. Editoria Científica 93(234): 423-442.

Gerbi, A. 1993. La disputa del Nuevo Mundo - bistoria de una polémica (1750-1900). México: Fondo de Cultura Económica.

Gomes, I.C.C. 2008. História e politicas da interiorização da UFPA na região oeste do Pará: das ações extensionistas à criação da UFPA. Monografia de Especialização. Universidade Federal do Pará. Belém: Núcleo de Altos Estudos Amazônicos.

Gonçalves, M.N. 2011. Cultura e educação ribeirinha na Amazônia paraense: teoria e práticas educativas inovadoras nas ilhas de Belém. Revista Maré 1:1-5. Disponível em: http://educampoparaense.org/revistamare/ 
sites/default/files/Vol1No0/CulturaEEducacaoRibeirinha.pdf

Gonçalvez, T.V. 2004. Educação em ciências e comunidade. Revista Brasileira de Pesquisa em Educação em Ciências. 4(2): 53-62.

Gondin, N. A.1994. Invenção da Amaz̧ônia. São Paulo: Marco Zero, 1994

Hage, S. M. (Org.). 2005. Classes Multisseriadas: Desafios da educação rural no Estado do Pará/Região Amazônica in Educação do campo na Amazônia: retratos de realidade das escolas multisseriadas no Pará. Belém: Gráfica e Editora Gutemberg Ltda.

2008. Educação do campo e os desafios do trabalho docente na Amazônia. Belém: ICED/ UFPA.

IPEA. 2012. Políticas Sociais: acompanhamento e análise. Desenvolvimento Rural 20: 247-254.

Lima, N. L. 2009. Educação, ciência e pesquisa na Amazônia: Um diálogo possível? lluminart 1 (3): 1-10.

Magalhães, L. L. 2009. O campo tem cor? Presença/ausência do negro no currículo da educação do campo no Pará. Dissertação de Mestrado. Programa de Pós-Graduação, Mestrado Acadêmico em Educação, Instituto de Ciências da Educação da Universidade Federal do Pará, ICED/UFPA, Belém.

Maués, O.C., M. Oliveira e A.J.S. Costa. 2006. A Educação Superior no Estado do Amapá. Vol. 1. Brasilia: INEP.

Melia, B. 1999. Educação indígena na escola. Cadernos CEDES 19(49): 11-17.

Nery, E. M. S., O. N. B. Souza, N. C. M. Oliveira. 2007. Educação do campo e poder local na Amazônia. Ciência e Desenvolvimento 3(5):77-92.

Oliveira, L. M. 2010. Educação do campo e currículo na Amazônia paraense. Dissertação de Mestrado. Programa de Pós-Graduação em Educação. Universidade Federal do
Pará, Belém/PA.

Oliveira, L. M. M. 2010. Educação do campo e currículo na Amazônia Paraense: o enfoque dado à diversidade sócio-territorial nas diretrizes curriculares da SEDUC/ PA. Dissertação de Mestrado. Programa de Pós-Graduação em Educação, Universidade Federal do Pará, Belém/PA.

Oliveira, R.N.V. 2006. A interiorização do ensino superior da UFPA e o curso de serviço social: uma relação a concretizar (1986-2006). Dissertação de Mestrado. Programa de Pós-Graduação em Educação, Universidade Federal do Pará, Belém/PA.

Rosemberg, F. 1985. Literatura infantil e ideologia. São Paulo: Global.

Silva, R.H.D. 1999. A autonomia como valor e articulação de possibilidades: o movimento dos professores indígenas do Amazonas, de Roraima e do Acre e a construção de uma política de educação escolar indígena. Cadernos CEDES 19(49): 62-75.

Silva, R.H.D. 2000. Escolas em movimento: trajetória de uma política indígena de educação. Cadernos de Pesquisa 111: 31-45.

Araújo, S. M. da S. 2007. A infância em meio a um sistema de significados (inter)relacionados: a criança nas salas de aula das escolas de fazenda da Ilha do Marajó in Educação Infantil e Estudos da Infância na Amazônia. Editado por C.M.P. Souza \& L. M. S. A. Alves, pp. 41-75. Belém: EDUFPA.

Ugarte, A.S. 2009. Sertões de Bárbaros: o mundo natural e as sociedades indigenas da Amazônia na visão dos cronistas ibéricos (séculos XVI-XVII). Manaus: Valer.

Unicef. 2011.O direito de ser adolescente: Oportunidade para reduzir vulnerabilidades e superar desigualdades. Brasília, DF: Fundo das Nações Unidas para a Infância.

Weigel, V.A.C.M. 2003. Os Baniwa e a escola: sentidos e repercussões. Revista Brasileira de 
Educação 22:5-13.

Wolochen, M. B; J. E. Souza-Lima, S. M. Maciel-Lima. 2009. A casa familiar rural e a pedagogia da alternância: Evidências de uma educação alternativa para o campo. Revista Científica Internacional 2(10): 1-22. Disponível em: http://www.researchgate.net/ publication/236342321_a_casa_familiar_ rural_e_a_pedagogia_da_alternncia_evidncias_de_uma_educao_alternativa_para_o_ campo.

Recebido em 10/01/2013.

Aprovado em 10/03/2013. 